\title{
Why issue bonds offshore?
}

\author{
Susan Black and Anella Munro ${ }^{1}$
}

\section{Introduction}

Bond markets in almost all currencies are becoming more internationalised (Table 1). ${ }^{2}$ Internationalisation of bond markets should increase the financing options available to borrowers and increase the range of assets available to investors. Competition from offshore markets may motivate or help to focus improvements in domestic markets such as strengthening of domestic market infrastructure, improving investor protection and removing tax distortions that hinder domestic market development. Swap-covered foreign currency borrowing can be a powerful means of raising domestic currency funding, overcoming the currency and maturity mismatches for many emerging market economies ${ }^{3}$ and a factor widely agreed to have exacerbated the Asian crisis.

Against these benefits come the risks associated with financial openness and sudden shifts in capital flows, and the risk that offshore markets may draw liquidity away from the domestic market. The former are well covered in the literature, and increasingly the risks associated with currency and maturity mismatch are well hedged in the region. However, risks to the domestic bond market are perhaps particularly relevant for Asian countries in the light of the many initiatives to develop domestic debt markets since the Asian crisis. If liquidity tends to concentrate in bond markets, development of a large offshore market in the local currency may be a concern. From the borrower's point of view local currency debt raised offshore may be as good as domestic debt. From a market point of view, there are likely to be important network externalities associated with reduced liquidity onshore, less scope for development of a lower-grade market in domestic currency, more limited availability of collateral for domestic markets and restricted access for domestic investors.

The literature on international bond markets focuses on three main aspects of the debt issuance decision: hedging/risk management, cost incentives to issue in foreign currency, and bond market characteristics that motivate offshore issuance such as size, payment structure and tenor.

The risk management literature ${ }^{4}$ focuses on issuance by non-financial firms and mainly applies to foreign currency borrowing which is naturally hedged against foreign currency income. The predominance of financial issuers in international bond markets, however, means that this strand of the literature, while an important motivation for some firms, covers a relatively small part of the market. A large literature on covered interest parity (CIP)

1 Susan Black is from Reserve Bank of Australia and Anella Munro from Bank for International Settlements. We are grateful for helpful suggestions from Philip Wooldridge, for comments from participants in seminars at the Bank for International Settlements; and for research assistance from Clara Garcia. The views expressed in this paper are those of the authors and do not necessarily reflect those of the Bank for International Settlements or the Reserve Bank of Australia.

2 We use "internationalised" to mean issuance of local currency bonds in offshore markets, issuance in the local currency by non-residents (on or offshore) and non-resident investment in domestic bond markets. In this paper we focus more on the issuer (as opposed to investor) side of bond markets.

3 Often referred to as "original sin" (Eichengreen and Hausmann, 1999).

4 For example see Allayannis and Ofek (2001), Kedia and Mozumdar (2003), Geczy, Minton and Strand (1997), Graham and Harvey (2001) and Siegfried et al (2007). 
suggests that deviations in cost incentives for bond issuance are actively arbitraged. ${ }^{5}$ McBrady and Schill (2007) link deviations from CIP and proxies for uncovered interest parity to the bond issuance decision, looking at "opportunistic" issuance by internationally active borrowers with no foreign currency funding requirements. They conclude that internationally active borrowers issue (swap-covered) foreign currency bonds to lower their funding costs and conclude that such borrowers actively arbitrage deviations from CIP and proxies for uncovered interest parity among major currencies.

Focussing on issuance costs rather than deviations from interest parity, Peristiani and Santos (2008) look at the costs of issuing bonds in the US domestic bond market and eurobond market. They find that costs in the US market have declined, but costs in the Euromarket have declined by more and are now lower. They relate the lower Euromarket costs to the growing share of offshore issues by US firms.

Other studies focus on or include bond market characteristics. This literature overlaps substantially with cost incentives: the benefits of bond issuance in overcoming differences in markets or market access, or in aligning desired funding with investors' preferences, tend to be reflected in lower funding costs. Baker et al (2002) look at the decision to issue short or long-term debt, finding that firms tend to issue long-term debt when the relative costs are expected to be less. Faulkender (2005) analyses the decision to issue fixed or floating rate debt, and whether firms are hedging or timing the market. He finds that firms respond to market conditions in an effort to lower funding costs; firms are more likely to lock in a lower fixed rate as the yield curve flattens and vice versa. Siegfried et al (2007) study the choice of currency by non-financial companies, finding that it is motivated by cost minimisation, hedging, the desire to establish a broader investor base and regulatory barriers. Munro and Wooldridge (2009) consider motivations for obtaining domestic currency funding through swap covered foreign currency borrowing as opposed to borrowing in domestic currency directly. They find that foreign currency issuance by Asia-Pacific residents tends to be lower rated, longer term and larger in size than non-resident issuance in Asia-Pacific currencies, consistent with the notion that swap-covered foreign currency borrowing provides AsiaPacific issuers with access to larger, more liquid, lower-grade and longer-term markets. Issuance by non-residents in the domestic currency meets investor demand for high-grade local currency assets.

This paper examines the onshore/offshore bond issuance decision by non-government residents of five Asia-Pacific countries. We consider a variety of potential motivations for offshore bond issuance, including: risk management; price arbitrage; the benefits of tapping offshore markets with different characteristics (liquidity, diversity, risk); accessing nonresident investors, regulatory and non-regulatory barriers to foreign investment in the domestic market; and funding diversification. We consider some of these motivations empirically using a large sample of unit record data for bonds issued by residents of Australia, Hong Kong, Korea, Japan and Singapore that covers issuance in both the domestic and offshore markets irrespective of issuance currency. A probit model links the decision to issue offshore to proxies for the benefits from doing so. The study supports the notions that (i) deviations from covered interest parity are actively arbitraged by residents of minor currency areas, as well as by internationally active borrowers as established in the literature; and (ii) issuers appear to benefit from access to larger, more diverse offshore markets. While price incentives are likely to be common to issuers from major and minor

5 See Taylor (1987) and Peel and Taylor (2002) for studies of short-term covered interest parity. Deviations from CIP in longer term markets tend to be small on average (Popper, 1983), suggesting either that bond issuers are arbitraging cost differentials or that swap spreads are adjusting. In longer term markets, deviations can be significant and persistent relative to short-term markets, even accounting for transactions costs (Fletcher and Taylor 1996). 
currency areas, residents from smaller markets may tap larger offshore markets for other more structural incentives such as overcoming market incompleteness. Indeed those structural benefits are likely to drive cost incentives and draw issuers from major markets into the domestic market. Against the potential benefits of using offshore markets, we consider the risks associated with offshore issuance including concentration of liquidity away from the domestic market and exposures highlighted by the recent financial crisis. Consideration of the wider international bond market provides context for discussion of domestic debt market development in the Asia-Pacific region.

Offshore markets may complement domestic market development, helping to focus improvements in domestic infrastructure, diversifying the overall local currency market, establishing a minor currency asset class, and providing an alternative means of resolving currency and maturity mismatch. Offshore markets may, however, provide a substitute to and draw liquidity away from the domestic market. In Hong Kong and New Zealand, the offshore market in local currency bonds rivals or exceeds the domestic market. Anecdotal evidence, however, suggests that policy can have a significant effect on the onshore-offshore choice in local currency. Weak infrastructure, a poor legal or information environment, weak domestic savings or taxes may drive issuance offshore. A lack of stable savings supply or borrowing demand may lead to illiquidity in the domestic market. Looking forward, we consider the potential for concentration of liquidity in the domestic currency market on- or offshore against segmentation of the two markets serving different needs, and the scope for integrated global markets.

The remainder of the paper is organised as follows. Section 2 provides an overview of bond issuance by Asia-Pacific residents and in Asia-Pacific currencies. Section 3 considers potential motivations for issuing bonds offshore. Section 4 assesses these propositions using unit record bond issuance data for Australia, Hong Kong, Japan, Singapore and Korea. Section 5 discusses the risks of offshore bond issuance and lessons from the recent crisis. Section 6 concludes.

\section{Asia-Pacific bond issuance}

Outstanding bonds issued by Asia-Pacific residents are shown in Figure 1. The tendency for non-government borrowers ${ }^{6}$ to issue bonds offshore varies markedly across countries in Asia-Pacific (Table 1). ${ }^{7}$ Countries can be broadly grouped into those where a significant proportion of bonds is issued offshore (Australia, Hong Kong, New Zealand, Philippines and Singapore) and those where offshore bond issuance is a small share of overall issuance (China, Indonesia, India, Japan, Korea, Malaysia and Thailand). ${ }^{8}$

It is useful to think of offshore issuance by residents in the following segments: (i) local currency issuance offshore, (ii) foreign currency issued offshore which is (a) swapped into

6 Although government bonds account for a large share of domestic issuance in many Asian countries, our focus is on non-government entities that make a commercial decision whether to issue a bond onshore or offshore. Government issuance is likely to take into account other factors such as its role in the development of the domestic market and providing a liquid domestic benchmark.

7 We consider "onshore" to represent bonds issued in the local or domestic market of the country in which the issuer resides, and issued in accordance with the regulatory jurisdiction and market conventions of that country (for example, prospectus or product disclosure requirements) regardless of the currency of the bond or the residency of the investor. "Offshore" covers all bonds that were not issued onshore.

8 Focusing on the share of issuance can mask the size of offshore borrowings; for example, the size of the offshore Japanese and Korean bond markets are large (more than US $\$ 100$ billion) though the domestic markets are much larger. 
domestic currency, (b) naturally hedged against export income and (c) uncovered (Figure 2 depicts the bond market from an issuer's perspective). There is a distinct segregation between currency and market for Asian bond issuance: onshore issuance is almost entirely in local currency, while offshore issuance in is mostly in foreign currency. Foreign currency issuance is concentrated in US dollars, although euro-denominated issuance has been gaining share since 1999. The share of local currency bonds issued offshore is low across Asia-Pacific countries, with the exception of Japan. ${ }^{9}$

For some countries, such as Australia and New Zealand, it is common to raise foreign currency funding offshore and swap the proceeds into local currency as a substitute for issuing domestic currency bonds directly. More than $80 \%$ of foreign currency liabilities in those countries are hedged with financial derivatives (Becker et al, 2005 and Statistics New Zealand, 2008).

The ability to swap foreign currency funding into domestic currency depends on the availability of a swap counterparty. The swap counterparty is typically a non-resident issuing domestic currency debt such as the World Bank (but generally with no use for domestic currency funding). In contrast to residents, whose issuance of local currency bonds is highly concentrated onshore, non-residents tend to issue local currency offshore (for example, a non-resident issuing New Zealand dollars in the Eurobond market) as shown in Table 2 and Figure 3. This is particularly the case in more open financial systems (such as Hong Kong, Japan, Singapore and New Zealand); non-resident issuance in these currencies is substantial and mostly takes place offshore. Australia is an exception among the more open economies, with larger non-resident issuance onshore (Kangaroo bonds) than offshore. At the other extreme, for some countries, such as China and Malaysia, the local currency is not traded offshore.

Foreign currency debt that is not hedged with financial instruments is often naturally hedged against foreign currency income, for example by exporters. Where foreign currency debt is not hedged with foreign currency income or financial derivatives, but used to fund domestic currency assets implies currency mismatch. Uncovered foreign currency borrowing is a financing structure that has declined significantly after the Asian crisis and is not discussed in detail here.

\section{Motivations for offshore issuance}

In this section potential motivations for issuing bonds offshore are considered under the general headings of hedging/risk management, price arbitrage, market completeness; barriers to non-resident investment in the domestic market and funding diversification. There can be a large degree of overlap among these groups. For example, benefits stemming from access to more liquid or diverse markets likely drive cost incentives to fill gaps in markets. In a liquid and complete market with inter-market capital mobility, there should be no scope for price arbitrage as prices can adjust to new information without trading. In the bond markets closest to this ideal, such as the US market, price differences are estimated to be arbitraged away relatively quickly. ${ }^{10}$ Where arbitrage involves a less liquid market, arbitrage opportunities may be relatively persistent. Moreover, motivations that stem from persistent differences in market characteristics, for example absence of a low-grade debt market in one

9 Our focus here is the issuer side of bond markets. It is worth noting that there are substantial non-resident holdings of local currency bonds in some domestic debt markets in the region, which is an alternative means of borrowing directly from non-residents in local currency.

10 Popper (1983), Fletcher and Taylor (19960. 
currency, may lead to persistent patterns of cross-border issuance, to maintain equal funding costs across markets. Offshore issuance in any one country may be driven by a combination of these factors, or others we have overlooked, for different reasons at different times.

\section{Risk management}

It is well known that firms with foreign exchange income may issue bonds denominated in a matching currency to provide a natural hedge for those cash flows. While this is a motivation to issue foreign currency bonds, ${ }^{11}$ rather than to issue offshore per se, foreign currency bonds are typically issued either as foreign bonds in the market of the currency of denomination (eg Singapore dollar bonds in Singapore) or in the Eurobond market (centred in London and other European financial centres).

Issuance in a foreign currency to match foreign currency income is likely to be an important motivation for non-financial corporates, especially exporters. Issuance by corporate borrowers, however typically accounts for a small share (on the order of 10\%) of total foreign currency issuance, with the bulk done by financial firms. Moreover, many residents borrowing offshore raise foreign currency funding that is swapped into local currency. ${ }^{12}$

\section{Price Arbitrage}

Banks often claim that they undertake opportunistic swap-covered foreign currency borrowing to lower their funding costs without taking on exchange rate risk. ${ }^{13}$ This type of borrowing itself should lead to a convergence of funding costs across markets consistent with CIP (local and foreign funding costs are equal once the cost of hedging exchange rate exposure is taken into account). Foreign currency issuance can affect both bond spreads and the cross-currency basis swap spread (quoted as the cost of swapping US dollars into another currency). The basis swap spread increases (decreases) in response to foreign currency issuance by residents (local currency issuance by non-residents), and in turn the decision by both residents and non-residents on where to issue is dependent on the crosscurrency basis swap. Moreover, cost incentives for offshore issuance are not limited to (swap-covered) foreign currency borrowing: issuance offshore in local currency may also respond to cost differences between onshore and offshore markets.

A large empirical literature on CIP finds that deviations are small on average but can be large and persistent, particularly for longer-term markets. McBrady and Schill (2007) take the CIP literature a step further, linking choice of issuance currency for a sample of internationally active borrowers with no operational reason to borrow in foreign currency to covered interest "bargains". They find that, covered "bargains" of between 4 to 18 basis points can be gained through opportunistic foreign currency bond issuance among major currencies. Here we explore that link in more detail including bond characteristics and macroeconomic factors as well as price incentives to issue in the chosen currency. These internationally active non-

11 We use the term "foreign currency bonds" to describe bonds denominated in a currency different from that of the issuer's residence and "local currency bonds" to describe bonds denominated in the same currency as that of the issuer's residence.

12 See Munro and Wooldridge (2009) for a discussion on the motivations for swap-covered foreign currency borrowing and the mechanics of this approach.

13 It is cheaper to raise local currency offshore than onshore when the spread to LIBOR that an issuer pays overseas plus the cross-currency basis swap premium they pay to a swap counterparty, is less than the spread to local currency LIBOR (or equivalent) that they would have paid in the onshore market. 
resident borrowers are an important part of the picture, being the natural swap counterparties to resident issuance offshore in foreign currencies to obtain domestic currency funding. ${ }^{14}$

\section{Market completeness}

Issuers may borrow offshore to access more or less "complete" bond markets, where differences in liquidity, diversity or risk characteristics lead to relative cost differentials. More complete markets are more likely to develop where there is a large, relatively heterogeneous investor base with varied risk preferences and a range of derivatives to transform risk. In general, borrowers from less complete markets are likely to be able to lower funding costs by using more developed markets. Similarly, issuers from more complete markets may be able to fill gaps in less complete markets, for example by creating a low default risk asset where sovereign credit quality is relatively low. These differences between markets may enable issuers to lower their funding costs by issuing offshore in a more or less developed market and swapping the proceeds into local currency.

Underlying potential benefits from differences in market characteristics is a need to match investors' preferences (liabilities) with borrowers funding needs (assets). The literature on preferred habitat ${ }^{15}$ considers the potential mismatch between investors' liabilities and borrowers' assets. For example, investors may prefer high-grade liquid assets while borrowers of varied credit quality may require funding for long-term projects. Premia offered to investors to buy bonds outside their desired risk classes may be ineffective in creating demand if supply and demand do not overlap at any price. Investors may ensure this by voluntarily creating barriers to investment in some asset classes, for example through mandates that restrict investments to high-grade bonds. This is often the case for managed funds in Australia, which tend to benchmark to a common, liquid, high-grade bond index. Swap-covered offshore borrowing provides a potential means of expanding the pool of savers and borrowers, increasing the scope for matching of assets and liabilities.

Some of the differences between markets that may give rise to benefits from issuance in offshore markets include:

- $\quad$ Sub-investment grade bonds: Low-grade markets are rare outside the United States and Euromarkets. In the absence of a developed domestic low-grade market, lowergrade borrowers may be able to access offshore markets while being limited to bank finance at home. ${ }^{16}$ Conversely, a high-grade non-resident counterparty may issue high-grade bonds in the domestic market to achieve lower costs for both parties. The availability of a liquid currency swap market will be important for offshore borrowing to be comparable on a risk-adjusted basis.

- $\quad$ Longer tenors: Longer-term markets tend to develop after shorter-term markets. The development of longer-term markets may be particularly slow in countries where investors avoid such investments due to a history of economic uncertainty or the sovereign benchmark yield curve is relatively short (Siegfried et al, 2007). In a relatively illiquid long-term market, issuance can be difficult or costly, particularly for lower-grade borrowers and for fixed rate bonds. Investors may also have a

14 Munro and Wooldridge (2009) explain that highly rated internationally active borrowers may be able to lower their funding costs by issuing in countries where there is a lack of AAA-rated bonds, reflecting a low sovereign ceiling or a small supply of government bonds.

15 See for example, Culbertson (1957), Modigliana and Sutch (1966), and Vayanos and Vila (2007).

16 See Hale and Santos (2008) on the progression from no access to funding to the sub-investment grade market to bank funding when the benefits of bank credit assessment overcome the intermediation cost, and ultimately to the investment grade bond market supported by a track record from bank borrowing. 
preference for a particular tenor so as to match their liabilities, whereas borrowers may prefer a particular tenor to match their assets.

- $\quad$ Fixed rate bonds: The fixed-floating nature in a particular dimension of the domestic market may vary according to idiosyncrasies of market development. Differences in liquidity in the fixed and floating segments of two markets, or differences in the credit quality gap for fixed term funding may lead to price differentials and opportunities for arbitrage.

- $\quad$ Larger deal size and total volume: Issuers may also tap offshore markets with a larger investor base so as to issue larger bonds (eg jumbo bonds greater than US $\$ 1$ billion), thereby raising more funds for a given fixed cost of arranging a bond issue, or to cumulatively raise more funds than they would be able to onshore. If the domestic market is relatively small or illiquid, large volumes of issuance may lead to adverse price movements.

- $\quad$ "Exotic" bond structures: More complicated bond structures, such as structured bonds with step-up coupons, tend to develop in deep liquid markets before they are available in smaller markets. While more complex bonds are likely to be structured to meet investor preferences, their development may be limited by investors' financial sophistication (particularly where the bond market is predominantly retail), by regulations constraining their use, or by a lack of a legal framework.

- $\quad$ Risk unbundling: From a non-resident investor's perspective, buying bonds in another currency typically means taking on currency risk (a non-resident investor typically does not have local currency liabilities). Local currency bonds have exchange rate risk, interest rate risk and credit risk. Market participants suggests that investors generally prefer to take on credit risk separately from exchange rate risk, $^{17}$ and that the markets for credit and currency risk are segmented. Risk unbundling may be particularly compelling if these risks are correlated (for example, during a crisis, domestic credit risk tends to rise while the currency depreciates). If two borrowers from different currency areas with much the same credit rating and characteristics each issue in the other's currency and swap the proceeds, they provide local investors in both countries with new assets in terms of the combination of currency, market and credit risk. ${ }^{18}$ By unbundling risks for investors, issuers may be able to lower their funding costs. Risk unbundling provides a persistent motivation for offshore issuance, even among well developed markets.

If borrowers are seeking to issue types of bonds for which there is little demand or insufficient infrastructure onshore, then issuance is most likely to be in larger, more complete markets, consistent with concentration of offshore issuance in US dollars, followed by euros. As the local bond market develops over time the motivations for Asia-Pacific residents to issue offshore may ease. Some motivations for issuing in offshore markets, however, such as risk unbundling may persist even among developed markets. The volume of cross border issuance between the US and Euro area markets suggests that some motivations are highly persistent. Volumes have certainly not diminished.

17 See also, Herrerra Pol (2004) who argues that strong demand for the World Bank's (highly rated) issues of international bonds in minor currencies is explained in part by investors' preference for taking on minor currency risk separately from credit risk.

18 Structured bond issues such as credit-wrapped bonds potentially provide an alternative means of transforming credit risk. These have been increasingly used in recent in more developed markets, but issuance has diminished sharply in the wake to the financial crisis in view of problems associated with complexity and the downgrades of the monolines that provided credit insurance. 
The availability of hedging instruments and liquidity in derivatives markets, particularly foreign exchange derivatives, is an important factor in the ability of issuers to arbitrage price differentials, and in turn affects the onshore-offshore issuance decision and the internationalisation of bond markets more generally. For countries that do not have liquid FX derivatives markets, issuers may be unwilling to raise foreign currency offshore because of currency mismatch. If hedging instruments are unavailable, then foreign investors are likely to be deterred from participating in the domestic market also, as they are unable to hedge their risks (Takeuchi, 2006).

In principle, investors could hedge the risks in issuers' desired funding, rather than issuers transforming the risk characteristics of their funding by issuing in offshore markets or foreign currencies. Investors could transform currency and credit risks using foreign exchange and credit derivatives (eg currency forwards and credit insurance) which in turn requires the availability of a liquid derivatives markets. It is probably more cost efficient for the issuer to swap its foreign currency borrowings back to its local currency than for a number of individual investors to hedge for a few reasons. Most issuers are banks and are regular participants in wholesale derivatives markets. Typically, issuers are dealing in larger amounts than investors, who have a small investment in each bond issue. Mandates - imposed by investors or regulations - may also restrict the use of derivatives.

Domestic savings also appear to play an important role in the development and liquidity of the onshore market. Tyler (2005) and Cameron et al (2007) argue that weak domestic savings and the related slow growth in the funds management industry have contributed to slow growth in the New Zealand domestic corporate bond market, with most residents issuing offshore instead. In contrast, Battellino and Chambers (2005) argue that the introduction of a compulsory retirement savings system in Australia in the early 1990s significantly boosted the domestic pool of investment funds, contributing to the development of the onshore bond market.

Finally, capital and exchange controls can have a major effect on offshore borrowing. Many of the potential benefits to offshore issuance discussed above depend on the ability to swap foreign currency funding into domestic currency. For that to occur, residents must be allowed to issue foreign currency debt, non-residents must be allowed to issue domestic currency debt, and both must have access to foreign exchange derivatives markets. Even if these are allowed, but other restrictions limit liquidity in FX derivative markets, price incentives may quickly disappear as swap costs move against issuers in the absence of prearranged counterparties.

\section{Barriers to non-resident investment onshore}

Offshore issuance appears to be an important means of tapping foreign savings. ${ }^{19}$ Much of the previous discussion focused on benefits to issuers from issuing in a foreign market, which in turn may reflect access to a broader investor pool. ${ }^{20}$ This section focuses on barriers to non-resident investment in the domestic market. Such impediments may include

19 The potential benefits of offshore issuance are also not restricted to countries with current account deficits. A country with no debt may have large gross assets and liabilities, whereby investors diversify by holding foreign assets and residents borrow from non-residents.

20 Data from the Australian Bureau of Statistics indicate that foreign investors own around $20 \%$ of bonds issued by Australian non-government residents in the domestic market, and own almost all of bonds issued offshore by Australian residents. 
regulatory barriers; information asymmetries; weak domestic infrastructure, information environment or legal environment. ${ }^{21}$

Regulatory barriers can affect foreign investors' ability to transact in the domestic (and offshore) market through capital and exchange controls. Non-residents have increasingly been allowed to participate as investors in regional markets as Asian countries have encouraged the development of domestic debt markets as a means of addressing the currency and maturity mismatches that were implicated in the 1997-98 Asian crisis.

Where non-resident investors are allowed to invest in the domestic market, in practice nonresident withholding tax has been a common disincentive to doing so. For example, Cameron et al (2007) argue that New Zealand banks and other issuers use offshore branches to issue bonds to avoid the "approved issuer levy". ${ }^{22}$ Similarly, in Korea, nonresidents are exempt from withholding tax for Korean bonds denominated in foreign currency but not domestic currency. ${ }^{23}$

Many aspects of domestic market infrastructure are important for attracting non-resident investment into the domestic market, including documentation requirements, the legal environment (bankruptcy proceedings), the information environment (opaque corporate governance or weak disclosure requirements) ${ }^{24}$, accounting standards, settlement systems and distribution and marketing channels. Non-resident investors are also likely to be deterred if clearing and settlement systems are not internationally compatible (Park and Rhee, 2006). ${ }^{25}$ Poor infrastructure, in turn, is likely to lead to illiquidity, particularly in lower-grade debt for which agency problems are more severe and the probability of default is higher. In response, investors may choose to buy bonds in more liquid offshore markets. Borrowers from a poor information environment may be able to signal that they are committing to higher standards by issuing offshore, which may lower their cost of funding and gain them access to foreign investors. ${ }^{26}$ Following the Asian crisis, there has been a focus in many Asian countries on strengthening market infrastructure including streamlining documentation requirements, improving the legal and information environment, reducing settlement risk and integrating domestic and international settlement systems. Many of these initiatives are discussed in detail in BIS (2006).

Agency and information problems are likely to lead to home bias in portfolio holdings, particularly for lower-grade debt. Some countries have weak disclosure requirements, poor accounting practices, opaque corporate governance rules and concentrated ownership structures. Low-grade issuers may be able to lower their cost of funding by issuing in

21 Ideally, foreign investors would participate directly in the domestic market as well as buying bonds offshore; they can help to broaden the investor base, which in turn may broaden the diversity of bonds issued onshore, and improve liquidity (Takeuchi, 2006).

22 A $2 \%$ charge on the value of the security levied on debt that is exempt from the non-resident withholding tax.

23 Asian Bonds Online http://asianbondsonline.adb.org/korea.php.

24 Local investors tend to be better informed than foreign investors, which can contribute to a home bias. Bae, Stulz and Tan (2008) found that the earnings forecasts of local investors are more accurate than those of foreign investors.

25 Battellino and Chambers (2005) detail the investment of market participants in improved market infrastructure, such as clearing and settlement systems, and in-house trading systems in the 1990s as an important factor in the development of the domestic bond market in Australia.

26 Banks also play an important role in overcoming agency and information problems. For example, Hale and Santos (2008) find that firms with a record of high creditworthiness and low creditworthiness enter the public bond market (investment grade market and high yield market respectively) before firms with an intermediate reputation. Moreover a firm's relationship with investment banks in connection with private bond issues and syndicated loans may speed entry into the public bond market by allowing the firm to signal higher credit quality. 
markets with greater creditor protection due to lower bankruptcy enforcement costs, especially for more complicated credit structures. Even if reporting standards are high in the domestic market, investors are more familiar with their home country issue requirements, such as the prospectus and settlement arrangements, and may have a preference for bonds issued in accordance with these. As a result, investors may hold a larger share of local assets in their portfolios than would be optimal in a well diversified portfolio. Stulz (1981) constructs a simple model of international asset pricing in which there is a cost associated with holding risky foreign assets and shows that investors will not hold some foreign assets, even if the return is increased slightly. ${ }^{27}$ Moreover, local investors tend to be better informed than foreign (distant) investors. For example, for a sample of 32 countries, Bae, Stulz and Tan (2008) find that local analysts' earnings forecasts are more precise than those of analysts based in countries far from the company being analysed.

Government regulations can also create incentives to issue onshore or offshore by altering the costs of funding in different markets. For example, during the global financial crisis, many governments have introduced guarantees of bonds issued by banks, though the currencies covered differ across guarantee schemes. The currency coverage of the guarantee is likely to affect the onshore/offshore decision and in turn which offshore markets banks choose to issue into. ${ }^{28}$ Central banks may also affect financing incentives through the collateral they accept in their lending operations, which is often restricted to high-grade bonds in domestic currency (which tend to be issued onshore). Bonds that are repo-eligible often trade at a premium, particularly during credit crises when liquidity is scarce which could draw issuance onshore (though other factors would also be at play during a crisis). ${ }^{29}$ The actions of other central banks can also affect onshore/offshore decisions if bonds issued by non-residents are repo-eligible in some countries and not in other countries.

\section{Funding diversification}

Issuers may also issue offshore for funding diversification. Financial institutions in particular, may value from a diversified funding base and use a variety of funding sources and instruments (for example, bank bills, bonds, deposits and securitisation) as well as diversifying across markets. The desirability of maintaining a presence in a market may be part of an issuer's risk management strategy. If one market was closed, the issuer could still access the other markets.

If entities issue bonds in offshore markets to diversify their funding sources, then one would expect diversification among the currencies raised, but there is a bias toward more liquid markets with issuance concentrated in US dollar and euro markets. In practice, issuers may not have allowed for a scenario like the recent global financial crisis where the most liquid bond market - the US market - was at the centre of the disruption. Pre-crisis, few could have

27 See also Stulz (2005) which discusses agency problems in the context of foreign investment and Alfaro et al (2005) which examines explanations for the Lucas paradox (the lack of capital flows from rich to poor countries) and finds institutional quality to be the most important.

28

While for some countries (such as Germany, the US, Sweden and Australia), the guarantee applies to all currencies, for others the range of currencies is wide though restricted to the major currencies (for example, the New Zealand guarantee covers NZD, AUD, USD, EUR, GBP, CHF, JPY, HKD, and SGD, the UK covers EUR, USD, JPY, AUD, CAD, CHF) and for others it is limited to a few currencies or just the local currency (for example, Portugal is restricted to EUR, and the Netherlands covers EUR, USD, GBP). While most schemes cover the local currency, there are some exceptions, such as Korea which covers foreign currency bonds only.

29 During the global financial crisis, many central banks have widened the range of collateral that is repo-eligible. Arguably this reduction in distortions across issuers is of greater significance than the introduction of onshore/offshore distortions for individual issuers that are now repo-eligible. 
imagined illiquidity in the US market. Going forward, funding diversification may be a particularly compelling motivation.

\section{Data and methodology}

Our empirical analysis links the choice to issue bonds offshore to potential benefits from doing so. Using a discrete choice (probit) model and unit record data for all bonds issued by non-government residents (including public banks and public non-financial corporations) of Australia, Hong Kong, Korea, Japan and Singapore, we find that the propensity to issue a bond offshore is related to price incentives, bond characteristics, bond market characteristics and macroeconomic variables.

The data for Australia are sourced from the Reserve Bank of Australia which draws on several commercial data providers, namely Bloomberg, Insto and Thomson Reuters, as well as market liaison. The data for Hong Kong, Korea and Singapore are sourced from Thomson Reuters. For Japan, the onshore bond data are sourced from Thomson Reuters, and the offshore data are obtained from the international securities database compiled by the BIS (which combines information from a number of commercial data providers, including Dealogic, Euroclear and Thomson Reuters). ${ }^{30}$

Characteristics recorded for each bond include: market of issue (onshore or offshore), date of issue, original term to maturity, deal size, currency, residency/nationality of issuer, industry sector, interest rate structure (fixed or floating), credit rating at issuance (not available for all bonds), sub-investment grade/investment grade. In addition, the data set for Australia also covers whether the bond is: credit-wrapped, structured, government guaranteed, repo eligible, whether non-resident withholding tax was applicable; and the bond spread at issuance.

Data are from 1992 to early 2009 for all countries. The sample sizes are large, though the number of observations varies substantially across countries from about 20,000 bonds issued by residents of Japan and Korea to about 7,000 for Australian residents, about 4,000 for Singapore and about 1,200 for Hong Kong. Not all bond characteristics and other variables are available for all bonds.

The empirical model is a probit model given by equations (1) and (2) which we apply to the unit record bond data:

$$
\begin{aligned}
y_{j, t} & =\left\{\begin{array}{cc}
1, & \text { if } y_{j, t}^{*}>0 \\
0, & \text { otherwise }
\end{array}\right\} \\
y_{j, t}^{*} & =\alpha \omega_{j, t}+\varepsilon_{j, t}
\end{aligned}
$$

The variable $y_{j, t}$ is a dummy variable that takes the value of one if the bond was issued offshore, and zero if the bond was issued onshore. According to equation (1), whether the bond is issued offshore is assumed to be the result of an unobserved latent variable $y_{j, t}^{*}$, which depends linearly on a vector $\omega_{j, t}$. that includes bond or market characteristics, pricing information, the current account and a time trend.

The specification for the probit model includes the following variables:

30 The offshore data for Hong Kong, Korea and Singapore are similar in aggregate to BIS data. The offshore data for Japan are BIS data which appear to be more complete than Thomson Reuters data in recent years. 
Size (log dollar value of the bond). We expect that larger bonds will be issued in larger /more liquid offshore markets.

- $\quad$ Tenor (log value). A potential motivation for issuing bonds offshore is to access longer term markets. We expect the coefficient to be positive for issuers tapping larger overseas markets. This is likely to be particularly true for lower-grade borrowers.

- Bond rating at issuance: Liquid low-grade markets are rare, so lower-rated borrowers may issue offshore to tap these markets. We use two measures for credit quality: (i) granular credit ratings $(A A A=1, A A+=2, A A=3$ etc), although availability of these data is patchy at best except for Australia where it is relatively complete (ii) sub-investment grade dummy, for which the coverage is good for all countries.

- $\quad$ Fixed interest rate structure. We do not have strong priors on the sign of this variable. The fixed-floating preferences of domestic investors and borrowers may vary across countries depending on the respective liability/asset structure. Highergrade issuers are expected to have a comparative advantage in issuing fixed rate bonds. Also, this may not reflect the bond issuers' ultimate interest rate structure, as they may swap from floating to fixed and vice versa.

Market size. The various aspects of market incompleteness discussed above are likely summarised by this variable. We expect the coefficient to be positive for the countries examined: a variety of characteristics of the US dollar and Euro markets provide incentives for offshore issuance. An important factor may be the networking externalities of larger markets. Market size is constructed as log of the size of the market in the currency of issuance normalised on the size of the US dollar market. So a US dollar bond has a value of $\log (100)$, a euro bond would have a value of about $\log (60)$, a yen bond about $\log (30)$, Australian dollar and Korean won bonds about $\log (2.5)$, Hong Kong and Singapore dollar bonds less than $\log (1)$ and New Zealand dollar bonds less than $\log (0.1)$. The values vary with relative market size over time. Source: BIS domestic debt data.

- $\quad$ Covered "bargain": ${ }^{31}$ Conceptually, the offshore bargain is the difference between what it would have cost to raise local currency funds onshore and the cost of raising local currency funding synthetically or directly offshore. ${ }^{32}$ We expect offshore issuance to be positively related to the covered bargain. We calculate the price incentive in two ways. Firstly, we use secondary market five-year bond yield indices for an AA-rated borrower, interest rate swap data and basis swap data (all from Bloomberg). For example the covered bargain on a US dollar bond issued by a Korean bank would be the spread of the five-year KRW yield over the domestic interest rate swap minus the spread of the five-year AA US dollar index over the US dollar interest rate swap adjusted for the won cross-currency basis swap. By construction, the incentive is zero for local currency issuance regardless of whether it is onshore or offshore (so we are not able to test the price incentive for local currency funding onshore versus offshore).

- $\quad$ Secondly, we use a more accurate transaction-based measure for a sub-sample of all senior one to five-year bonds issued by the major Australian banks since 2000. This measure is constructed from primary market spreads onshore and offshore

31 We borrow this terminology from McBrady and Schill (2007).

32 What it would have cost to issue onshore instead of offshore is not directly observable unless a borrower issued bonds with equivalent characteristics in both markets at the same time. Nonetheless, if the domestic secondary market is sufficiently liquid it should provide a good proxy for the opportunity cost. 
(adjusted by the relevant swaps) for the bonds at issuance and secondary market onshore spreads for the same sample of banks (historically, the secondary market has provided a very good indication of the banks' issuance spread in the primary market in Australia). This methodology is not only more accurate, but allows us to compare the cost of raising (i) $A \$$ directly onshore (ii) $A \$$ synthetically offshore and (iii) $A \$$ directly offshore. Restricting the sample to the Australian banks also has the benefit of removing bond issues that may not be hedged through derivatives; the Australian banks swap back their foreign currency raisings to $A \$$ at the time of issuance. This measure of the price incentive lines up relatively well with our alternative proxy discussed above.

- $\quad$ One-year interest rate differential (issuing currency minus home currency) at the time of bond issuance. We include this as a proxy for uncovered interest parity (with a random walk exchange rate expectation, the interest differential is the expected uncovered interest return). While the covered bargain may be more relevant for borrowers, the expected uncovered return may be relatively more important for investors, as we have seen with the carry trade in recent years. The interest differential also has a wider economic interpretation as the return to capital. We expect residents of borrowing countries issuing foreign currency bonds (almost always offshore) to issue bonds in lower yielding currencies of net savings countries as a means of accessing investors in countries where the return to capital is relatively low. Source: Bloomberg.

- $\quad$ Current account balance as a per cent of GDP at the time of bond issuance. We introduced this variable as a proxy for domestic funding pressures. If there are barriers to foreign investment in the domestic market (e.g. information asymmetries, market risk, withholding tax) or investors have a preference for currency and credit risk to be unbundled, then borrowers may be more likely to issue offshore to access non-resident investors when the economy as a whole is borrowing from nonresidents. We expect offshore issuance to increase when domestic savings cannot cover investment. For residents of external surplus countries (Hong Kong, Japan, Singapore), offshore issuance by domestic intermediaries may increase as a means of matching domestic investors' preferences with foreign assets, for example to provide foreign currency assets in a known name, while providing counterparty funding for non-resident borrowers who issue in the local currency. Source: Australian Bureau of Statistics and BIS data.

- $\quad$ Time trend. We include a time trend to account for the internationalisation of bond markets generally. This is perhaps particularly relevant for Singapore, where exchange controls were eliminated in 1999 and all onshore and offshore segments of the Singapore dollar bond market have grown rapidly since. In general, we expect offshore issuance to increase over time.

- $\quad$ Global financial crisis dummy. This is set equal to one from July 2007. It is intended to capture any effect the crisis may have had on the propensity to issue bonds offshore.

For Australia we also looked at:

- $\quad$ Australia managed funds/GDP as a measure of domestic savings which we expect would draw issuance onshore. The time series variable is matched to the issuance date of the bond. Source: Australia Bureau of Statistics.

An important characteristic of probit models is that they are highly non-linear; the estimated probabilities and marginal effects of any independent variable are conditional on the values of all covariates. This means that if the value of one of the independent variables changes, the marginal effect of all of them will also change. Accordingly, our discussion focuses on the 
sign of the coefficient; a positive (negative) sign indicates that as the variable increases (decreases) so does the probability of offshore issuance.

\section{Empirical results: factors motivating offshore issuance}

In this section we begin by examining the role of individual factors on the onshore-offshore issuance decision, and then estimate multivariate probit models to allow for interaction among these factors. Finally, we examine subsamples of the bond data to inform on different motivations among sectors. Where relevant, we comment on the impact of the global financial crisis.

The distributions of the bond characteristics listed in the previous section for onshore and offshore bonds are shown graphically in Figure $4 .{ }^{33}$ Univariate probit estimates are presented in Table 3 to illustrate the potential explanatory power of each of these factors on its own on the onshore-offshore decision. Overall, these bond characteristics have modest explanatory power. Characteristics with relatively stronger explanatory power are issuance of larger bonds offshore by Hong Kong, Korean and Singapore residents, issuance of smaller bonds offshore by residents of Japan, and issuance of lower-rated bonds offshore by residents of Singapore. Notably, residents of Australia, Korea and Singapore have only issued subinvestment grade bonds offshore. Offshore issuance by Korean residents is more likely to have a floating rate coupon than onshore issuance.

Multivariate estimates presented in Tables 4 and 5 give an idea of the relevance of the factors conditioned on other bond market characteristics, price incentives and macroeconomic conditions.

Table 4 includes individual bond characteristics as well as price incentives and macroeconomic conditions. The coefficients on bond size and tenor are positive, indicating that offshore bonds tend to be larger in size and longer in maturity. This is consistent with the notion that Asia-Pacific residents borrow offshore to access more complete, liquid markets. The exception is Japanese residents who issue smaller bonds offshore (consistent with Japan being a relatively large market), though the onshore/offshore distributions are very similar with most bonds being less than US\$0.5 billion (Figure 4). For other countries, the issuance of jumbo bonds (greater than US1\$ billion) is relatively common; these tend to be issued offshore.

The results for credit quality are a bit more nuanced. The only countries for which we have a substantial sample of bonds with granular ratings are Australia, Hong Kong and Japan. For those countries, credit quality, as measured by the credit rating, suggests that higher-rated residents are more likely to issue bonds offshore. However, the results for the subinvestment grade dummy suggest that residents are more likely to issue lower-rated bonds offshore. As seen in Figure 4, sub-investment grade bonds are almost exclusively issued offshore.

These seemly conflicting results are consistent with the story Hale and Santos (2007) tell about the relationship between bond markets and bank borrowing, which would imply a nonlinear pattern. The lowest-rated entities don't borrow at all. As potential borrowers progress to a somewhat higher credit quality, they issue bonds in the sub-investment grade

33 The graphs show the distribution of bonds by value rather than by number, which, arguably, investors care more about. The probit model tests the distributions by number. However, the distributions by value and number are very similar for all characteristics with the exception of the tenor of bonds issued by Japanese residents; by number, issuers go offshore for longer tenors, but by value the result is the opposite (consistent with Japan being a relatively large market). 
market. At a higher credit quality the intermediation cost of bank borrowing becomes worthwhile due the lower borrowing cost from a higher revealed credit quality. Finally, as a potential borrower can signal high credit quality without bank intermediation, but helped by its track record with the bank, the intermediation cost of a bank is no longer offset by a lower borrowing cost. Setting the Hale and Santos model in an international context it would be expected that lower-grade borrowers would borrow offshore in the absence of a domestic low-grade market and higher-grade borrowers might take advantage of relatively liquid and diverse offshore markets.

These results support the idea that residents issue offshore to tap more liquid low-grade markets and more liquid or diverse high-grade markets. They may also reflect the potential benefits from unbundling of risk implicit in swap-covered borrowing. Lower-rated bonds issued offshore (in foreign currency) and swapped for higher-rated bonds issued in local currency by non-residents (see Munro and Wooldridge 2009) provide potential investors with bonds with different risk characteristics compared to each party borrowing in the desired currency. In particular, foreign investors are able to purchase minor currency risk separated to a large degree from credit risk.

The effect of coupon structure on the propensity to issue offshore is mixed. Residents of Japan, Korea and Singapore are more likely to issue floating rate bonds offshore while Australian and Hong Kong residents are more likely to issue fixed interest rate bonds offshore. The coupon structure may not reflect the ultimate interest rate exposure of resident borrowers for two reasons. First, borrowers may subsequently swap the funds for their desired coupon structure but borrow fixed or floating rate debt in response to cost structures determined by their own characteristics (eg credit quality) and investors' preferences. For example, higher-rated institutions (such as the Australian banks, who are the main offshore borrowers from Australia) may have a comparative advantage in issuing fixed rate bonds. Australian banks have floating rate mortgage assets, so tend to swap their fixed rate borrowing to floating. Second, the coupon structure may reflect the desired interest rate exposure of swap counterparties rather than the bond issuer if the (foreign currency) proceeds are swapped for local currency funding. Of note, Figure 4 shows that while Australian residents are more likely to issue fixed rate bonds offshore than onshore, overall they have a greater tendency to issue floating rate bonds (63\% of offshore bonds and $75 \%$ of onshore bonds are floating). Bonds issued by residents of Korea and Japan show the opposite tendency, with around $65 \%$ of offshore bonds and over $90 \%$ of onshore bonds being fixed (where data are available). Borrowers may also issue fixed or floating rate debt in an attempt to lower their funding costs, depending on their expectations of future economic conditions, rather than hedging their asset exposure (Faulkender, 2005).

Table 5 includes market size in place of bond characteristics as a proxy for characteristics of the issuing market and other factors not captured such as liquidity and infrastructure. The notion that issuers tap offshore markets to take advantage of larger, more liquid and more diverse markets, is reinforced by the positive coefficient on market size. Offshore bonds tend to be in the currencies of a larger market. Market size serves as a proxy for a range of bond market characteristics including liquidity, diversification of products and investors and is typically correlated with the bond characteristics listed above. As can be seen in Table 3, market size has a larger explanatory power than the individual bond characteristics in the univariate probits. This result holds up in the multivariate estimates for some countries where it is included as an alternative to the individual characteristics (Table 5).

Because not all data are available for all bonds, the multivariate results are typically based on smaller samples. In the multivariate probit regressions (Table 4) the relationship between offshore issuance and size and tenor is not as strong. Accounting for other factors, Australian issuers are estimated to issue onshore for longer tenors and larger bonds (not a highly significant result) while Hong Kong and Japanese investors are estimated to issue offshore for longer tenors. These results are discussed in more sectoral detail later. 
The pricing incentive to issue offshore is measured as the covered interest "bargain" (the deviation from covered interest parity) and the interest rate differential which we use as a proxy for the expected uncovered interest return. While we assume borrowers hedge their foreign currency borrowing, investors may be more likely to take uncovered positions (eg the carry trade).

The literature on covered interest parity shows that, for shorter maturities, deviations from parity tend to be small and short-lived (the 2008-09 experience notwithstanding). In longerterm markets, deviations tend to be larger and more persistent, and so may provide an important incentive in terms of currency of issuance. A bargain in a particular currency may lead residents to issue in that currency and swap the proceeds back into the desired currency. As shown in the univariate results in Table 3, the coefficient on the covered interest bargain (denoted CIP) has a positive sign except in the case of Japan, where the explanatory power (pseudo R2) is very small. In contrast, for Australian and Korean borrowers, the bargain has strong explanatory power. In the multivariate probit estimates (Table 5), the covered bargain is estimated to be positive as expected (significant for Australia and Hong Kong, near-significant for Korea and not significant for Japan) except in the case of Singapore, where it is not significant.

Measurement error is a concern with the CIP variable for a number of reasons. First, we are using yield indices rather than transaction costs and those indices may be subject to interpolation where there a relatively few securities for pricing. ${ }^{34}$ Second, we assume our representative borrower to be an AA-rated bank. While this is a reasonable proxy for the major banks in the countries examined, the measure may be inappropriate for the lowergrade borrowers in our sample and for countries subject to changing ratings through the period. Nevertheless, we think that a deviation from covered interest parity at one horizon and credit quality is likely to be correlated with other horizons and credit ratings for the same currency. We expect that our covered cost estimates are least accurate for Hong Kong, as they are based on a sovereign index, and for Japan in view of the changes in ratings of Japanese borrowers over the period, which we do not account for. Third, not all foreign currency borrowings are swapped back to local currency, some of it is naturally hedged or it may be not hedged at all. However, this should bias our sample against finding issuance behaviour consistent with swap covered arbitrage.

As a cross-check on our pricing results we use more accurate issuance spreads available for a sub-sample of Australian major banks. Here the pricing data is based on actual issuance costs relative to the domestic secondary market. These results, shown in Table 6, are consistent with the broader Australian results, indicating that the banks borrow offshore when it is cheaper to do so. Using actual issuance costs, we are also able to test whether the banks issue Australian dollar offshore versus onshore for cost reasons. While the estimated coefficient is the expected positive sign, it is not highly significant for this small sample (Figure 5). Studies by the Reserve Bank of Australia (2006) have found that, on average, costs (after hedging) have been equivalent onshore and offshore over time for the major Australian banks. Short-term cost differentials arise at times, which leads to issuance in a particular market, though the banks' issuance itself then contributes to driving costs back towards parity (Figure 6).

The significance of the covered bargain is important relative to the outstanding literature that examines bond issuance in response to deviations from parity. The only paper we know of that does this is McBrady and Schill (2007) which looks at internationally active opportunistic

34 Moreover, although we have matched the rating of our onshore and offshore indices, there are different banks in the various countries' indices so the margin could reflect factors other than price arbitrage such as credit risk or liquidity premia. We are also unable to distinguish between costs of local currency borrowing onshore and offshore. 
borrowers' currency choice among major currencies using sovereign yields which may include a substantial measurement error. Based on that evidence, they conclude that those international borrowers are active arbitrageurs among major currencies. Here, with the exception of Japan, we examine borrowers from smaller currency areas, and the results suggest that they are also active arbitrageurs in the market. In fact, the benefits for issuers from minor currency areas of accessing larger markets may be an important driving force in price incentives for non-resident investors to issue in the minor currency, and potentially more so if local bond markets are relatively small or less diverse than those in major currency areas.

The interest differential serves as both a proxy for expected uncovered interest returns and the return on capital in different countries. In practice, the higher returns on capital in one currency provide a rationale for the carry trade whereby capital flows from low return on capital areas to higher return on capital areas (higher yield currencies).

The estimated coefficients for the interest differential in Table 3 are positive for Hong Kong, Japan and Singapore and negative for Australia and Korea. These results hold for the multivariate estimates where significant. As we expect capital to flow from countries with a low return on capital to those with a high return on capital we might expect this variable to be negative for high yield countries which tend to have external liabilities, and positive for lower interest rate countries that tend to have external asset positions. By issuing in lower yield currencies, borrowing countries may gain better access to savers in high-saving countries. Conversely, banks in high savings countries may issue bonds in high yield currencies as a means of providing a more diversified class of assets for domestic savers (such as high yield foreign currency bonds issued by a known name) while lending the proceeds to borrowers in a high yield country. While the returns to capital should, in theory, be arbitraged away as capital flows to areas with a higher return on capital, in practice the process may take decades. For example, a low-capital economy that wishes to double its capital stock could, in theory, borrow $100 \%$ of GDP in year one (run a current account deficit of $100 \%$ of GDP) and repay the funds over time. In practice, current account deficits of more than 10\% of GDP are rare. Instead, a low-capital economy may run a persistent current account deficit over decades to achieve the same outcome and convergence on capital returns. In that context, the result that net borrowing countries issue bonds in currencies with a low return on capital and vice versa appears to make sense.

The results for the current account balance tell a similar story. As shown in Table 3, the coefficient on the current account balance is negative for Australia (suggesting that a larger current account deficit increases the probability of issuing offshore), not significant for Korea and positive for Hong Kong, Japan and Singapore. For Australia, a net borrowing country, a current account deficit implies that the country as a whole is borrowing from non-residents. This could be achieved by selling domestic bonds to non-resident investors. If, however, there are barriers to non-resident investment onshore (eg information asymmetries, home bias in investor preferences, correlated risks), then residents may issue bonds offshore as a means of accessing foreign investors. In that case we would expect to see a negative coefficient: a current account deficit increases the probability that the bond is issued offshore. For a country with an external surplus, a resident bank may be flush with domestic savings, but needs to find profitable investment opportunities. Banks from surplus countries may overcome aspects of market incompleteness or repackage risks for domestic savers by issuing bonds in borrowers' currencies and swapping the proceeds, or lending the foreign currency proceeds to foreign residents. In that case a larger current account surplus might be expected to be associated with a higher probability that bonds are issued offshore. We could have used the absolute value of the current account balance as a measure of borrowing and lending with non-residents but, as the countries in our sample have tended to run persistent deficits (Australia and Korea) or surpluses (Japan, Singapore and Hong Kong), the results would be qualitatively the same. In the multivariate regressions (Table 5), the same results 
hold qualitatively, but are less significant once other factors (such as the interest differential) are taken into account.

The time trend serves as a proxy for factors not captured in our analysis that trend over time, particularly those that contribute to the increasing internationalisation of debt markets. The estimated univariate coefficients are positive for all countries except Singapore where the trend is not significant. The removal of capital controls and other barriers to internationalisation of debt markets and the development of derivatives markets that enable residents to take advantage of larger markets may be captured here. In the multivariate equations, the results are very mixed. Evidence of a trend toward greater offshore issuance over time, is not robust once other variables expected to affect the issuance decision are accounted for. While, offshore (and non-resident) issuance in Asia-Pacific currencies grew rapidly in the years leading up to the international financial crisis, domestic debt markets are also growing rapidly (Figures $2-3$ ). We discuss the potential shift offshore in more detail in the policy section discussion later in the paper.

For Australia, we also included variables for repo eligibility, availability of a government guarantee, presence of non-resident withholding tax and the size of managed funds/GDP as a proxy for domestic savings. Repo eligibility was expected to draw banks' bond issuance onshore, whereas the government guarantee could work either way as it was available for both onshore and offshore issuance. Non-resident withholding tax, which was applicable for onshore bonds sold to non-residents for part of the sample was expected to drive bond issuance offshore while a larger pool of domestic savings was expected to draw bond issuance onshore. Although the dummy variable for repo eligibility was estimated to have had a significant effect in drawing bank issuance onshore (Table 7), acceptable collateral was widened during the global financial crisis, and so may equally reflect the crisis, ie difficulty in raising funding offshore during that period. When we include both repo eligibility and the crisis dummy, only the crisis dummy is found to be significant. The available of a government guarantee also coincided with a mild shift toward onshore issuance, but like repo eligibility, was not estimated to be significant in the presence of a crisis dummy. Anecdotally, these factors can have a strong influence on the offshore/onshore issuance decision. For example, Australian banks were the first to issue government-guaranteed bonds in Japan during the global financial crisis, as they were one of the few countries whose guarantee extended to Japanese yen bonds. Overall, the onshore shift during the crisis was modest with banks expanding issuance both on- and offshore.

The effect of the non-resident withholding tax and supply of domestic savings should apply more broadly than banks. The non-resident withholding tax is estimated to not be significant. Anecdotally, the removal has a significant effect on non-resident issuance (growth of the Kangaroo bond market) which is outside our sample of issuance by residents. The ratio of managed funds/GDP as a proxy for domestic savings is estimated to be negative and significant, suggesting that as the supply of domestic savings increases, bond issuance is drawn onshore.

The global financial crisis dummy was included to pick up factors that may have affected the onshore/offshore motivations and the fact that markets were not functioning normally during this time. As shown in Table 8, it is significant and negative only for Hong Kong. For Australia and Singapore it is negative and significant for the financial subsample suggesting some tendency to issue onshore during the crisis, possibly reflecting stress in offshore USD markets in particular and home bias among investors amid uncertainty. Overall, the crisis period is marked more by a general fall in issuance rather than a major shift in its location. For example, during the credit crisis Australian securitised bonds have only been issued onshore. While this partly reflects government purchases of residential mortgage-backed securities (RMBS) onshore from late 2008, it is mostly due to the disruptions in the US securitisation market, which was at the centre of the crisis; structured investment vehicles (SIVs) were used to purchase around a third of Australian RMBS before the crisis. Nonetheless, offshore issuance by the major Australian banks' offshore issuance has been 
stronger during the crisis than beforehand, supported by government guarantees that apply to offshore as well as onshore bonds.

\section{Sectoral results}

Tables 9 and 10 present results for financial and non-financial issuers and Table 11 presents more detailed sectoral results for Australia. Both financial and nonfinancial issuers are more likely to issue larger, lower-rated bonds offshore, with the exception of Australian financial institutions which issue both smaller and shorter tenors offshore and Japanese financial institutions which issue smaller bonds offshore. Looking at sectoral estimates for Australia (Table 11), the smaller offshore issuance size and shorter tenor appears to be related to bank issuance, particularly minor banks. The smaller banks' offshore issuance is skewed toward shorter maturities than their onshore issuance. One factor that might explain this is particular bond structures whereby many small tranches are issued under one set of documentation such as medium-term note programmes. In the unit record data these show up as several smaller bonds. Also, in recent years, some of the major Australian banks have also been issuing more exotic bonds offshore (such as step-up coupon bonds). These types of bonds tend to be relatively small and have only been issued offshore.

As shown in Figure 4, sub-investment grade bonds are almost exclusively issued offshore. The relationship between offshore issuance and credit quality may also involve other factors and vary by sector. For Australia, financial institutions are more likely to issue higher-rated bonds offshore while non-financial corporates, which issue most of the lower rated Australian bonds, are more likely to borrow offshore. Moreover, Australian corporates rated about BBB have tended to issue "credit-wrapped" bonds onshore - bonds that are guaranteed by monoline insurers to achieve an AAA rating (though many of these have been downgraded during the global financial crisis). This reflects strong demand by domestic investors for highly rated bonds due to investment mandates of managed funds. Lower-rated Australian corporates have not used credit enhancement when issuing offshore (so we are not able to control for credit-wrapping in the probit regression). At the other end of the credit quality scale, the larger and higher-rated (typically AA) Australian banks, who are better known overseas, have tended to be more prolific users of offshore funding than the smaller, lowerrated Australian banks which rely more on domestic funding (where they are better known).

Financial issuers are estimated to be more likely to issue offshore in search of price arbitrage, which is consistent with their more sophisticated financial skills. Non-financial issuers are estimated to be less motivated by price, perhaps consistent with a risk management motivation: the currency rather than the domestic currency with higher implied cost is what matters. Non-financial corporate offshore borrowing is almost exclusively in foreign currency.

In summary, our results suggest that, unsurprisingly, price arbitrage is an important motivator, possibly the most important, for issuing offshore. This is particularly the case for financial issuers whose issuance, in turn, contributes towards funding costs being equalised onshore and offshore. Market completeness and liquidity are also estimated to drive issuance decisions. This may be underestimated here to the degree that benefits from completing markets are reflected in price incentives. The results are also consistent with the notion that borrowers from net deficit currencies issue offshore to access foreign investors in net surplus currency areas, possibly by unbundling credit and currency risk and seeking to overcome barriers such as withholding taxes. It is difficult to test how important funding diversification is. Liaison with the Australian and New Zealand banks indicates that it is a factor they take into account in their funding decision. Consistent with this, they issue in a relatively wide range of currencies (Figure 2). It appears to be less of a consideration for offshore issuers from some other countries who predominantly tap the US market when they issue offshore, though this may reflect the expectation prior to the global financial crisis that the US dollar markets were unlikely to suffer a significant disruption. 


\section{Policy lessons and risks}

The preceding discussion focuses on the potential benefits for domestic issuers from tapping offshore markets; but the use of offshore bond markets can pose risks to the borrower, the liquidity of the domestic bond market, and the financial stability of the borrowing economy.

The risks of unhedged foreign currency borrowing are well known. While currency mismatch may be a problem for some issuers, the experience of 2007-08 suggests that uncovered foreign currency borrowing is no longer a major issue in the Asia-Pacific region. Hedging surveys for Australia and New Zealand show that the vast bulk of offshore foreign currency borrowing is swapped into local currency financing. Of the remainder, most is naturally hedged against foreign currency income. As experienced during the Asian crisis and the 2007-08 period, foreign currency funding can be subject to foreign liquidity pressures and disruptions for short term foreign currency funding (eg trade credit) and rollover of longerterm foreign currency funding. It can be equally disruptive to local currency markets when borrowers who are unable to roll over funding in international markets turn to local markets with the intention of borrowing in local currency and converting the loan proceeds into foreign currency. As recent events have illustrated, mechanisms for using reserves to provide foreign currency liquidity can be an important part of risk mitigation.

Swap-covered foreign currency borrowing carries little currency risk, but is a more complex form of borrowing which involves other risks. ${ }^{35}$ The greater complexity of swap-covered borrowing requires more sophisticated risk management capabilities on the part of both borrowers and supervisors. Moreover, refinancing risk involves not one bond market, but liquidity in both the foreign exchange swap market and the underlying funding markets on both sides of the swap. Disruptions in either of the funding or hedging markets can lead to problems in refinancing. ${ }^{36}$ Rollover concerns are greater still if non-residents, who tend to make up the bulk of investors in offshore markets, are a less stable funding source during a crisis than domestic investors.

The experience of countries in the Asia-Pacific region that rely heavily on offshore funding, such as Australia and New Zealand, during the global financial crisis suggests that the risks can be managed effectively, especially for highly rated borrowers. Their resilience highlights the importance of a variety of factors, including: well capitalised banks with good risk management, widespread hedging of foreign currency borrowing, scalable domestic currency liquidity provision, strong fiscal positions and high sovereign ratings, and flexible exchange rates (see Munro and Wooldridge, 2009 for a more detailed discussion of risks). Where foreign currency borrowing was hedged (effectively domestic currency denominated borrowing), local currency liquidity provided a substitute for external funding and rollover requirements declined in foreign currency terms as local currencies depreciated. For Australian banks, as with other banks internationally, AAA government guarantees helped to maintain offshore market access.

Diversification of funding sources across markets may mitigate refinancing risk, though less so if liquidity pressures are correlated across markets. During the 2007-08 financial crisis, although funding pressures in the US market spread to other integrated markets, diversification appears to have provided some benefits, with borrowers continuing to tap less disrupted markets and entering new ones such as the Japanese Samurai market (Japanese yen bonds issued in Japan by non-residents).

\footnotetext{
35 A well functioning domestic bond market with an established yield curve from which derivatives can be priced, helps to develop a derivatives market (Burger and Warnock, 2003).

36 Refer to Munro and Wooldridge (2009) for further discussion of the risks of swap-covered borrowing.
} 
Turning to macro financial stability, some countries may be concerned that offshore issuance may result in an increase in foreign indebtedness. Those borrowers previously restricted to borrowing onshore or not at all, might be able to access cheaper funding or a wider pool of funding. Greater access to external funding might in turn lead borrowers to increase financial leverage, financial risk (particularly if the debt is denominated in foreign currency or short term) and external indebtedness. These risks of offshore borrowing will of course depend on the risk management capacity of both borrowers and regulator and need to be weighed against the costs of financial autarky and the potential benefits of financial integration such as scope for consumption smoothing in response to shocks and pressures to allocate capital more efficiently (see Henry 2006 for a review), and other more nuanced and catalytic institutional benefits (Kose et al 2006).

A common concern is that offshore borrowing, which is mostly swap-covered foreign currency debt, may draw liquidity away from the domestic market. Swap-covered borrowing itself does not necessarily reduce the size of the local currency market. Rather, it changes the composition of issuers in the local currency market from domestic borrowers to nonresident borrowers (who issue local currency debt and swap it to their preferred currency). ${ }^{37}$ However, non-resident issuance is highly skewed toward offshore markets, consistent with a loss of liquidity in the domestic market.

Because of network externalities and economies of scale in financial markets, liquidity tends to concentrate (Committee on the Global Financial System 1999), and there is a risk that it may tend to concentrate offshore. Indeed, the value of outstanding bonds issued offshore in Hong Kong dollars and New Zealand dollars is greater than onshore issuance (Table 2). Factors that would favour concentration of liquidity in the domestic market are a steady volume of government issuance, stable demand from domestic investors who want domestic currency assets (foreign investors' demand for local currency assets is likely to vary in response to exchange rate expectations), better assessment of domestic credit risk, especially in the case of lower-grade borrowers. The offshore market, however, offers lower costs, including a lack of withholding taxes and lower issuance costs. Peristiani and Santos (2003) report that underwriting costs in the eurobond market are now lower than in the US market, suggesting an absolute advantage, even in US dollar debt. Consistent with this, US dollar international debt markets (issuance by non-residents and by residents offshore) increased from about one tenth the size of the domestic debt market in the mid-1990s to about one third in 2007. There are advantages to a deep onshore market including availability of collateral for other domestic financial markets; access to a liquid market for domestic borrowers; better access for resident investors; the tendency for transparency to be greater onshore; and the contribution of a developed bond market to a more efficient banking system. ${ }^{38}$

Rather than a concentration of liquidity in the domestic or offshore market, the two may provide potentially complementary segments. For example, onshore markets tend to serve domestic borrowers and investors, while offshore markets tend to serve non-resident borrower and investors. While competition from an offshore market is likely to expose weaknesses in the onshore market, a dose of competition may provide the incentive to improve domestic infrastructure and the regulatory, legal or information environment, leading

37 The experience for Australia and New Zealand is that non-resident issuance in the domestic market does not crowd out local issuers (Battellino and Chambers, 2005 and Tyler, 2005). Non-resident issuance pushes down the cross-currency basis swap, making it cheaper to issue offshore and swap back the proceeds into local currency.

38 Borensztein and Panizza (2006) find that banks and bond markets are complements, with bond market development contributing to the development of an efficient banking system. Banks provide bond underwriting services, bridging finance prior to issuance, bond distribution channels and are major issuers of bonds. 
to a more efficient onshore market. In that case, offshore issuance may accelerate the development of the overall local currency bond market to the benefit of all borrowers. Battellino and Chambers (2005) argue that domestic financial institutions' first-hand experience in the offshore bond market helped to develop a financially sophisticated workforce which contributed to the development of a deep domestic bond market in Australia. If the onshore market infrastructure is weak, offshore issuance may usefully help to establish a minor currency as an asset class. Offshore markets, however, may concentrate a large segment of higher credit quality liquidity (Eurobonds are usually rated A or above) away from the domestic market and high-grade liquidity can be important for the development of lower-grade segments.

The balance between on- and offshore issuance is subject to policy influence, including simplicity of registration requirements, market infrastructure, transactions costs, withholding taxes, greater legal certainty and more efficient payment and settlement systems. Some onshore markets have competed more successfully than others. Issuance in the Kangaroo bond market (Australian dollar bonds issued onshore by non-residents) soared over the 2002-06 period due to a combination of factors. While a minimum volume of government issuance may be important to establish benchmarks, a fall in the supply of government debt securities left unfilled demand for high-grade local currency assets, a gap that was filled by high-grade non-residents. Second, growth in domestic demand for high-grade domestic currency securities was provided by pension funds and broadening of assets accepted by the central bank as collateral, Removal of non-resident interest withholding tax lowered costs. ${ }^{39}$ It is worth noting that these policy changes were not intended to promote the domestic market, but reflected fiscal prudence, growing domestic pension savings, removal of preferential restrictions on collateral, and the principle of taxation in the place of residence. The policy shift was more a case of removing barriers to onshore market development than promoting it.

Rather than domination or segmentation, the advent of global bonds (issued in more than one market), suggests development toward an integrated global bond market (Miller and Puthenpurackal, 2005). Such a path may require a degree of convergence in both issuance requirements among markets and settlement platforms. To date global bonds account for a very small share of overall issuance. Another path to a global market might be integration of market access standards. Mutual fund recognition via acceptance of each others' registrations between Hong Kong and Australia provides a recent example of such integration (ASIC 2008). If liquidity concentrates in bond markets because of network externalities, then integration of networks may make location of issuance less important for local currency bond market liquidity.

While the offshore market may offer a substitute for a weak domestic market, development of the domestic debt and streamlining of domestic market infrastructure are likely to complement overall market development. Much has been done in recent years, particularly in Asia, to develop domestic local currency bond markets infrastructure and environment including developing local rating agencies, streamlining documentation requirements, developing settlement systems, and improving the legal and information environment (many of which are documented in Bank for International Settlements, 2006). Domestic market quality has moved toward best practice, markets have become more liquid, sovereign umbrella ratings have risen and an increasing number of regional currencies have become more established asset classes. Complementary to the development of domestic markets, foreign exchange controls on non-resident buying of assets in domestic debt markets have increasingly been eased.

39 In 2007-08, non-resident issues of New Zealand dollar bonds shifted toward onshore issuance after they became repo eligible. 


\section{Summary}

Asian bond markets, like bond markets globally, are becoming increasingly international in terms of offshore and non-resident issuance in the local currency. This paper set out a variety of motivations for offshore bond issuance by residents, and used a discrete choice (probit) model and unit record bond data for five Asia-Pacific countries (Australia, Hong Kong, Japan, Korea and Singapore) to link the issuance decision to potential benefits. Our results support the idea that (i) deviations from covered interest parity are actively arbitraged by residents of minor currency areas, as well as by internationally active borrowers among major currencies as established in the literature; and (ii) issuers benefit from the liquidity and diversification of larger "complete" offshore markets. The latter conclusion appears to be particularly true for lower-rated borrowers. Sub-investment grade bonds are almost exclusively issued offshore, reflecting the rarity of sub-investment grade markets outside the United States. Against the potential benefits to borrowers, we consider the risks, for both borrowers and the domestic market, and lessons from the financial crisis such as funding diversification. The many initiatives undertaken in Asia-Pacific countries in the past decade and those underway such as the ASEAN+3 Credit Guarantee and Investment Mechanism, remain highly relevant for both domestic markets development and for taking advantage of the potential benefits offered by international bond markets. 
Figure 1

Bonds issued by Asia-Pacific residents

US\$ million outstanding

Australia

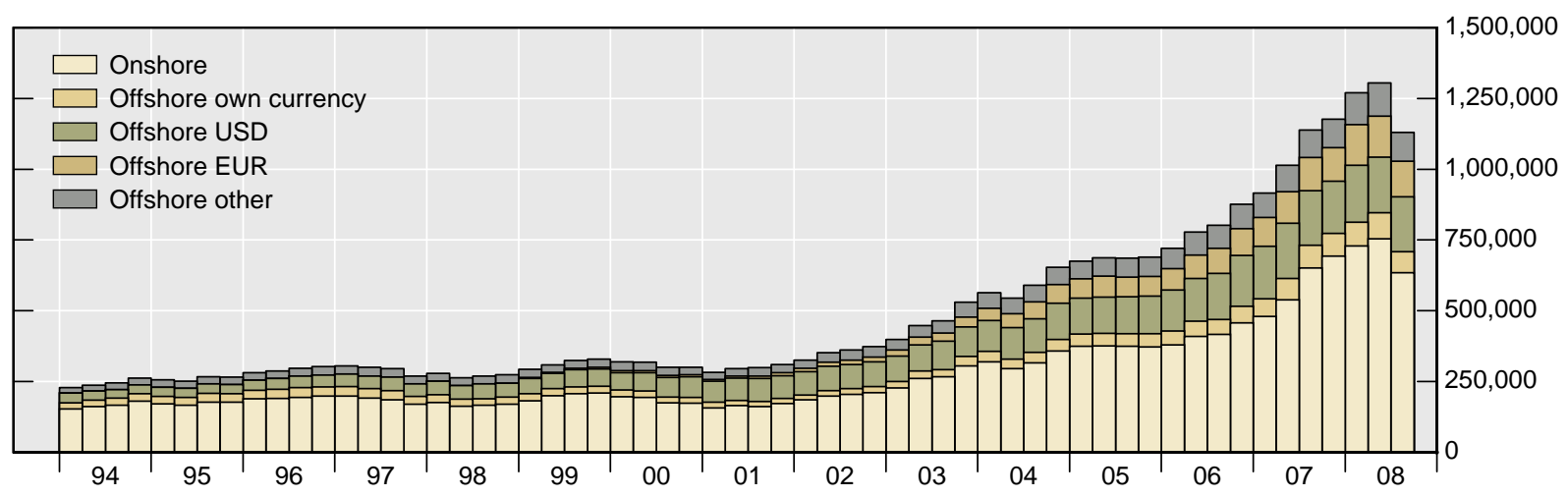

China

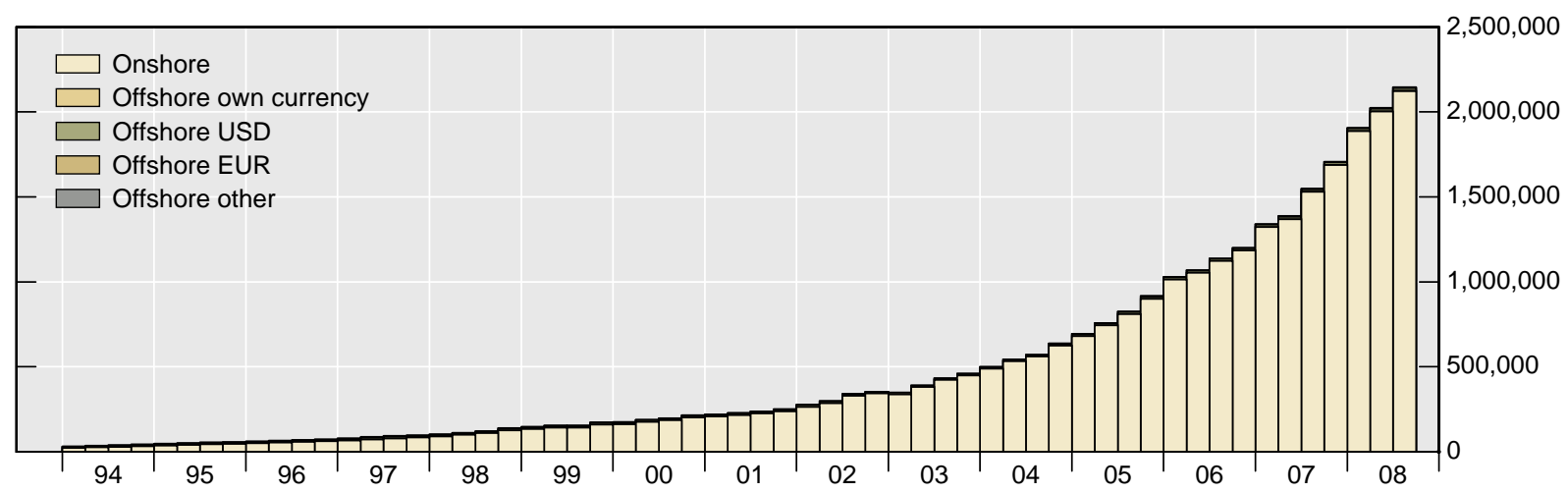

Hong Kong

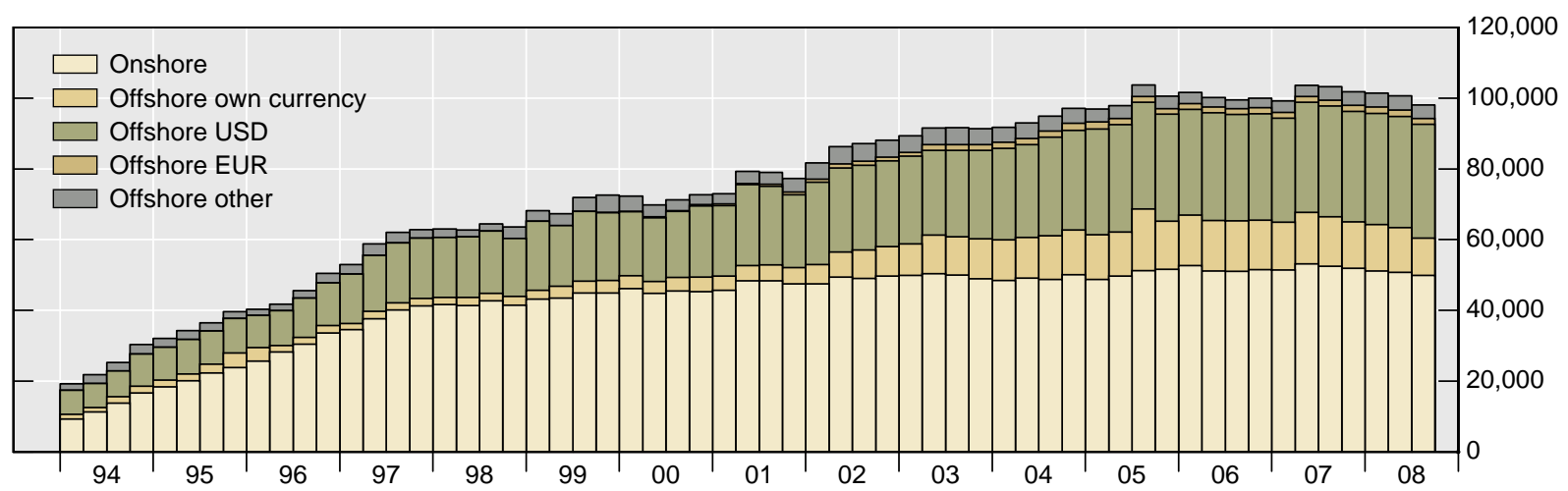




\section{Indonesia}
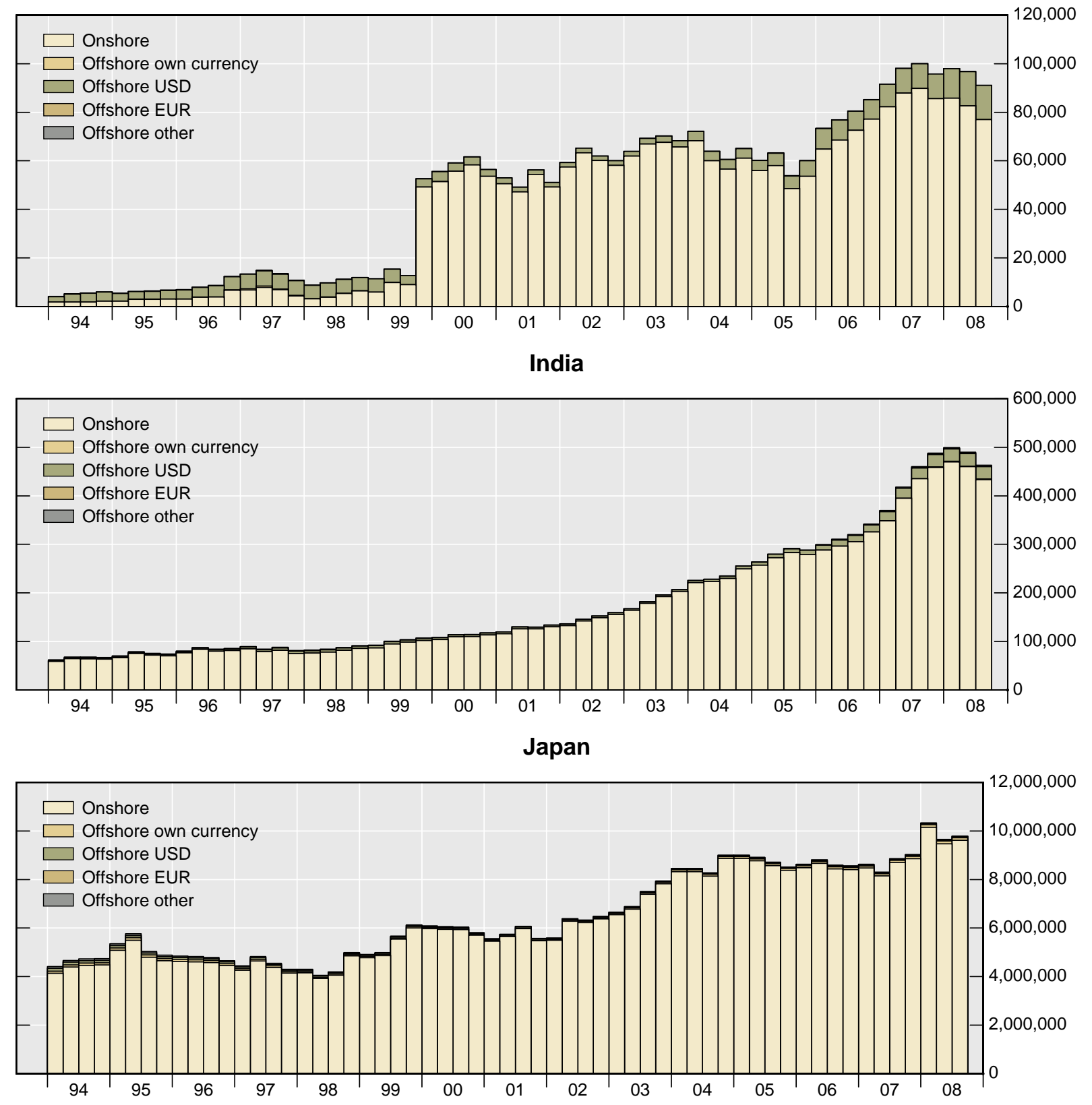

Korea

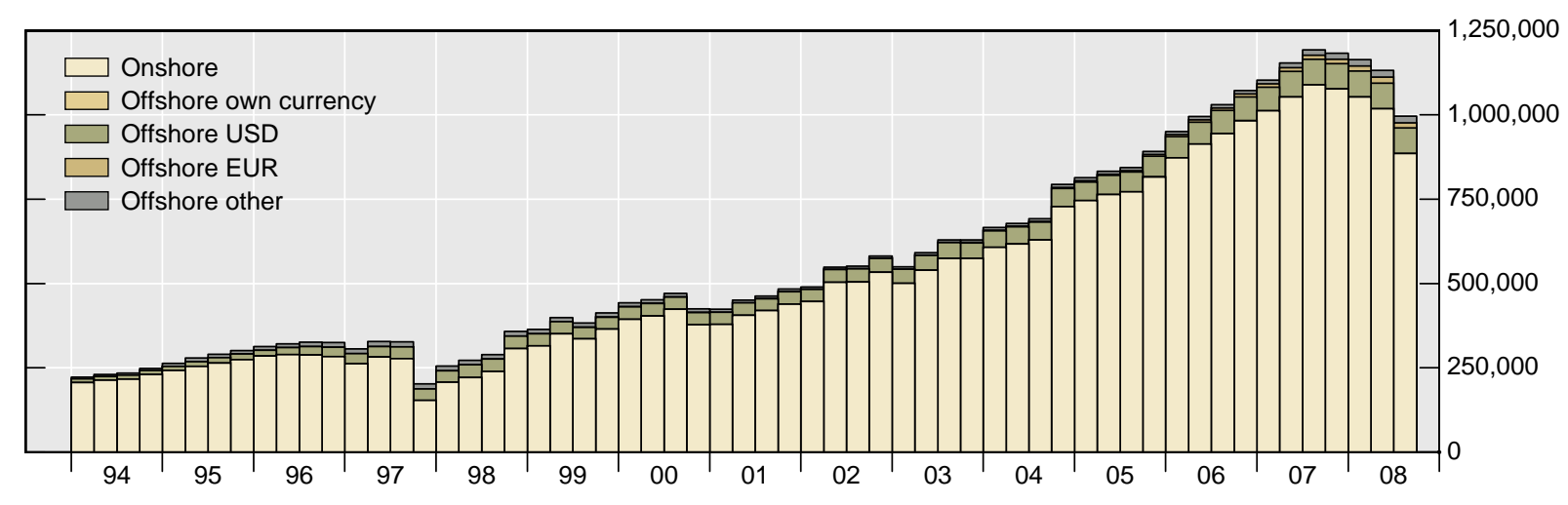


Malaysia
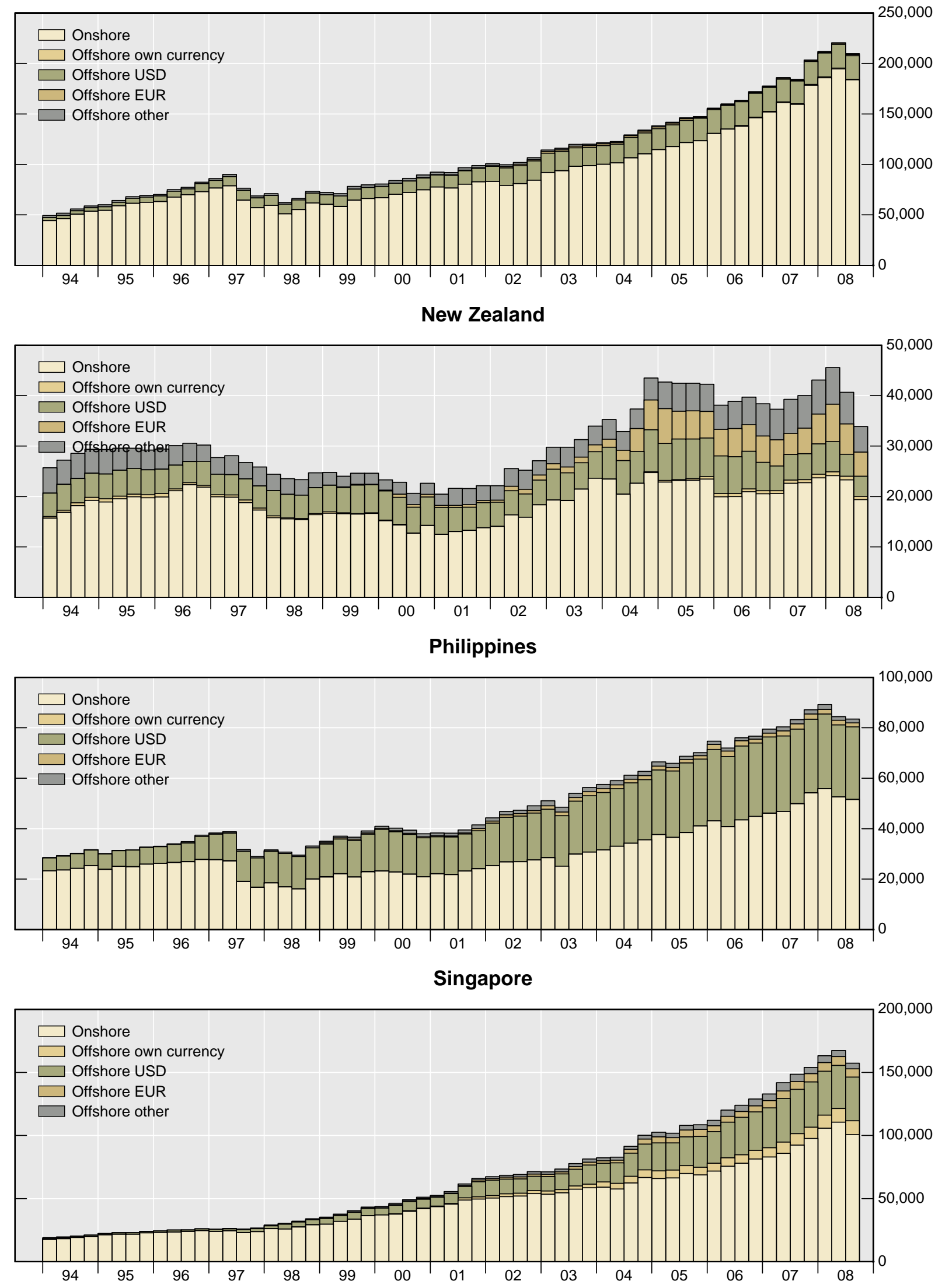
Thailand

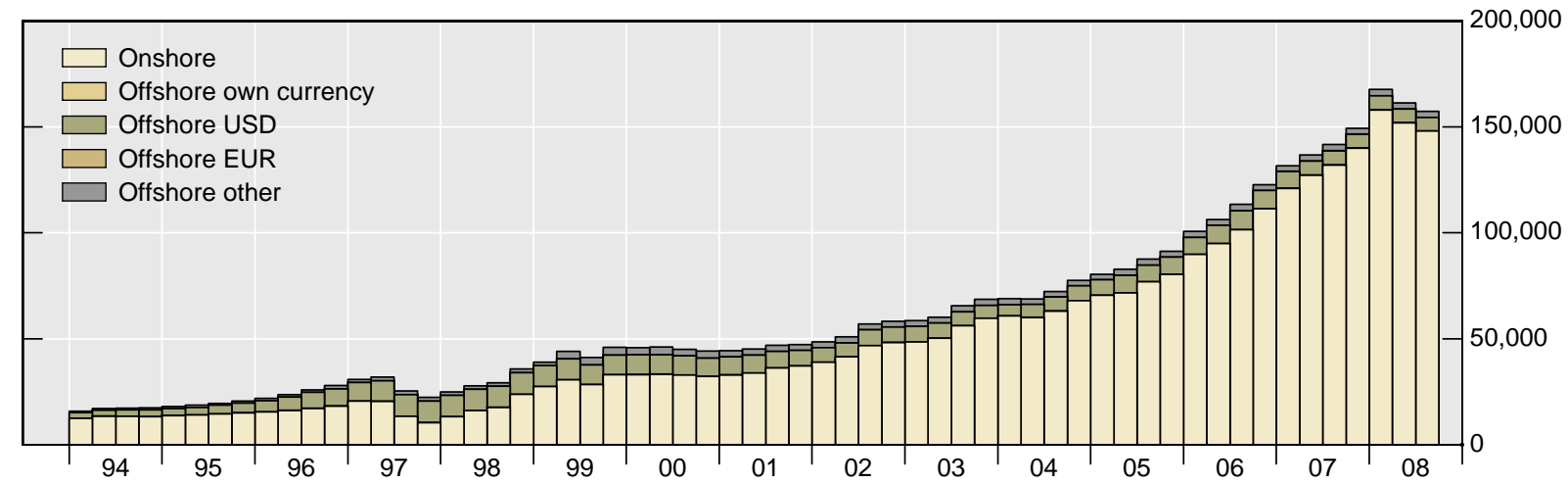

Source: BIS.

Figure 2

Stylised view of bond market: domestic issuer's perspective

\begin{tabular}{|c|c|c|c|}
\hline \multirow[b]{2}{*}{ Onshore } & \multicolumn{2}{|c|}{ Residents } & Non-residents \\
\hline & \multicolumn{2}{|c|}{$\begin{array}{l}\text { Domestic debt market } \\
\quad \text { (local currency) }\end{array}$} & $\begin{array}{l}\begin{array}{l}\text { Foreign bonds } \\
\text { (local currency) }\end{array} \\
\text { e.g. Arirang, Kangaroo, Kauri, } \\
\text { Saphurai }\end{array}$ \\
\hline \multirow{4}{*}{ Offshore } & \multicolumn{2}{|c|}{ Eurobonds: local currency } & \multirow{4}{*}{$\begin{array}{l}\text { Eurobonds } \\
\text { local currency }\end{array}$} \\
\hline & \multirow{3}{*}{$\begin{array}{l}\text { Eurobonds } \\
\text { foreign currency }\end{array}$} & $\begin{array}{l}\text { export } \\
\text { income }\end{array}$ & \\
\hline & & $\begin{array}{l}\text { swap- } \\
\text { covered }\end{array}$ & \\
\hline & & uncovered & \\
\hline
\end{tabular}

Note: Arrows indicate likely cross-currency swap counterparties. 
Figure 3

\section{Onshore and offshore issuance in Asia-Pacific currencies ${ }^{1}$}

Amounts outstanding

\section{Australian dollar}
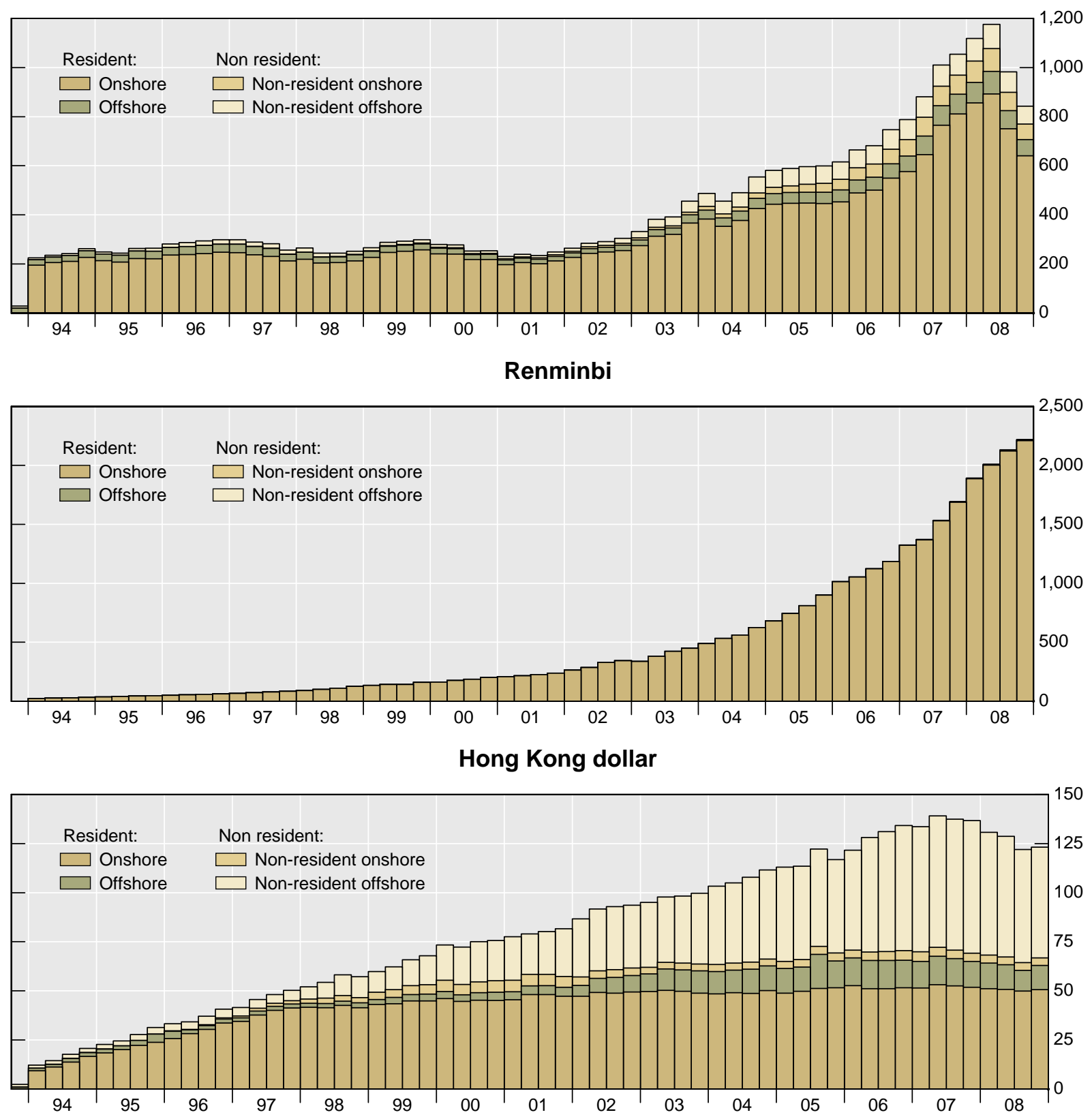


\section{Rupiah}
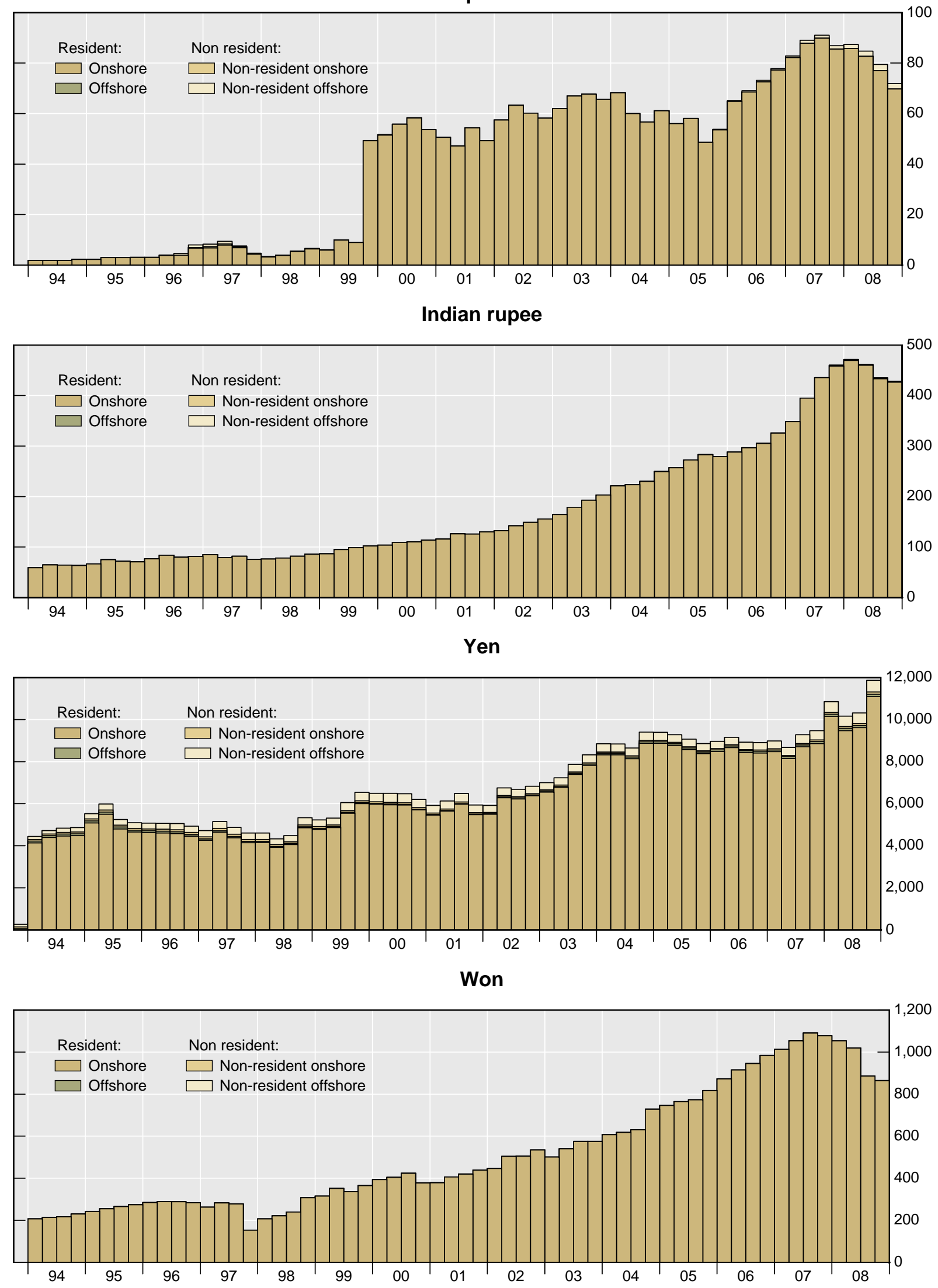
Malaysian ringgit

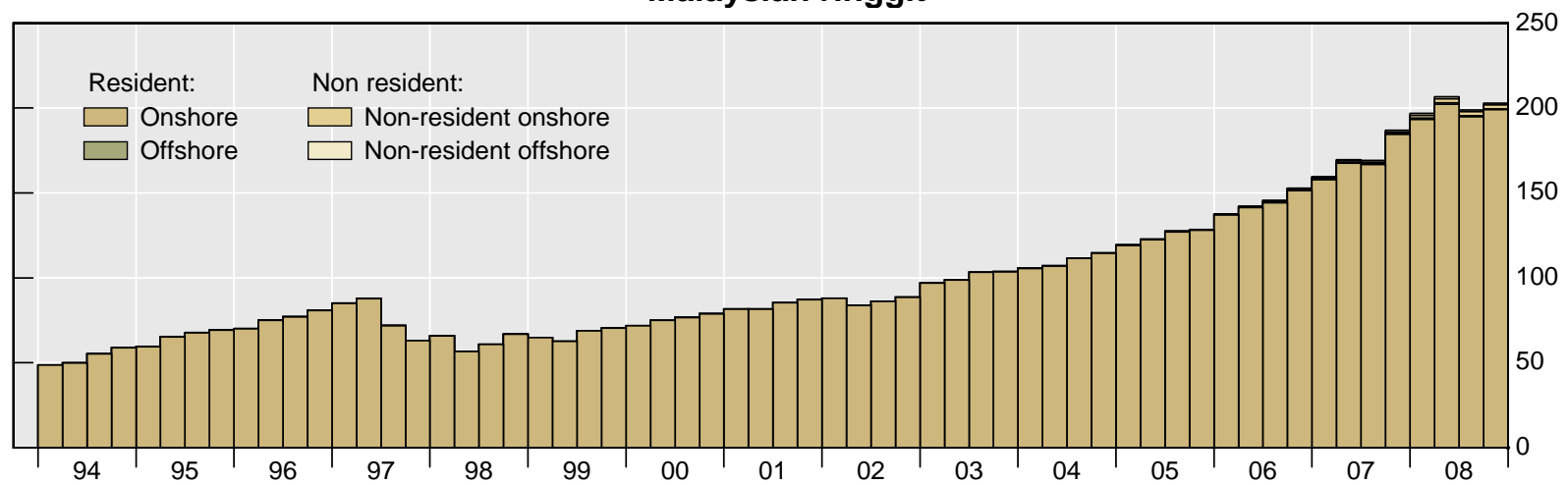

New Zealand dollar

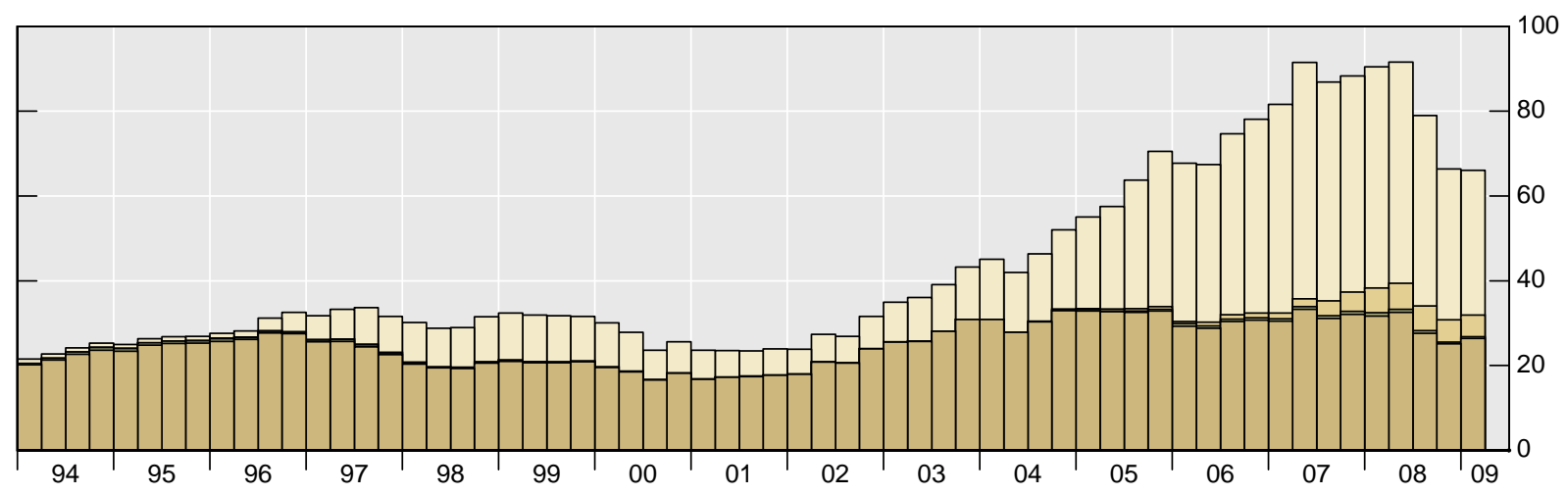

Singapore dollar

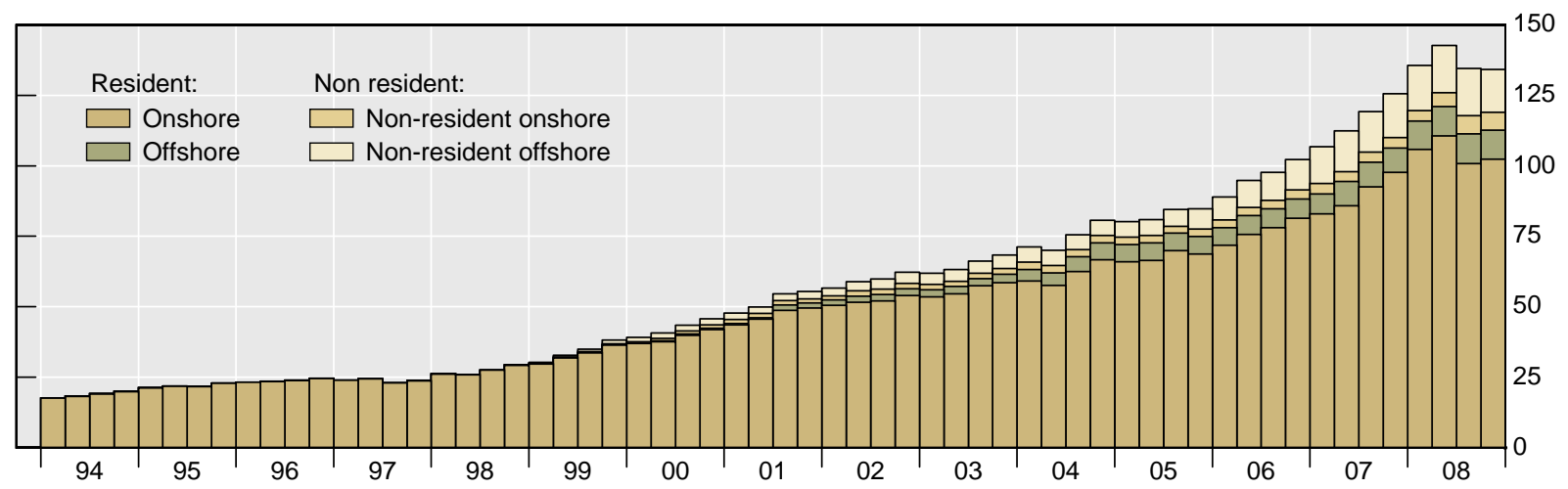


Figure 4

\section{Bond characteristics}
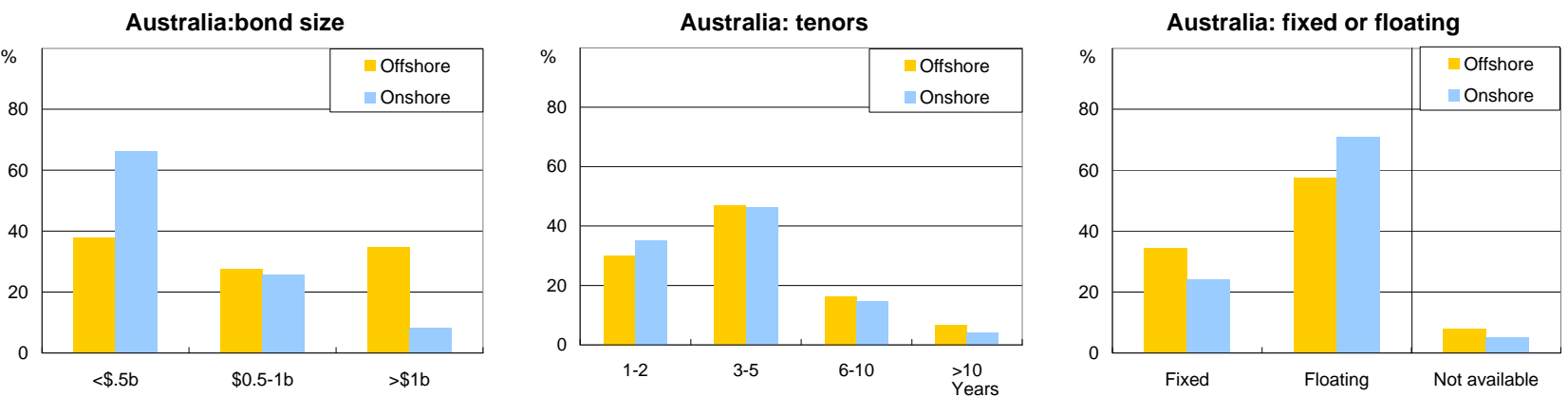

Hong Kong: bond size

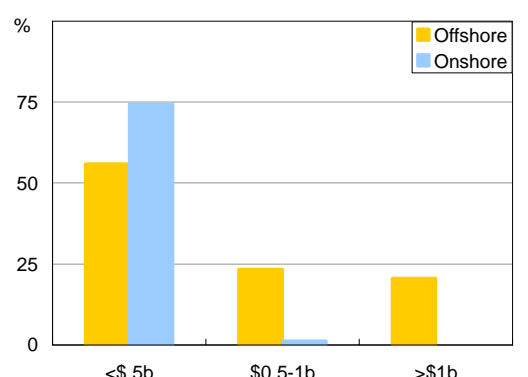

Hong Kong: tenors

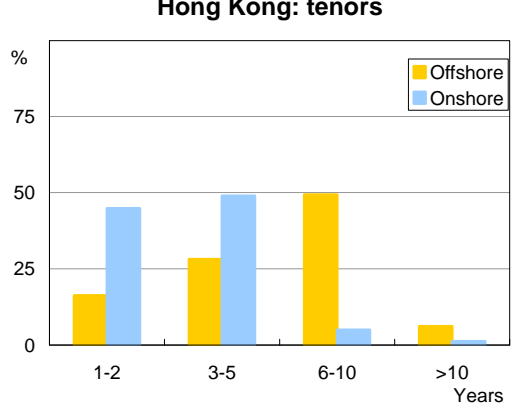

Hong Kong: fixed or floating
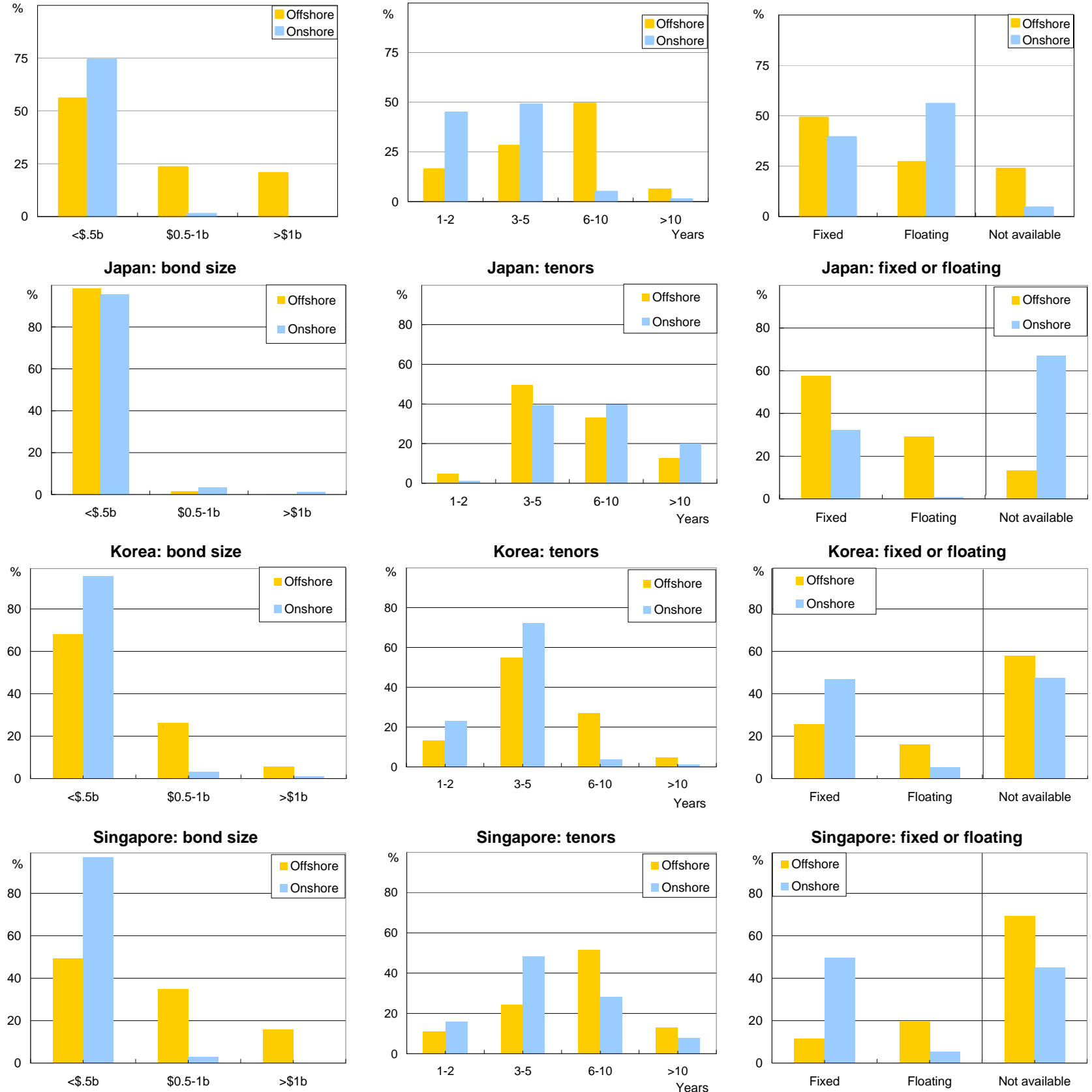
Australia: credit rating

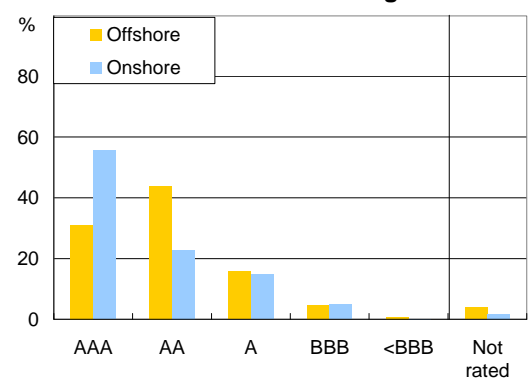

Hong Kong: credit rating

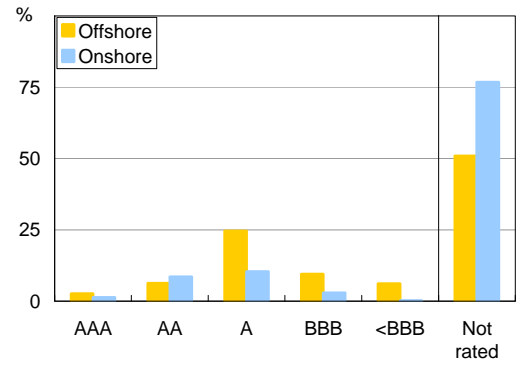

Japan: credit rating

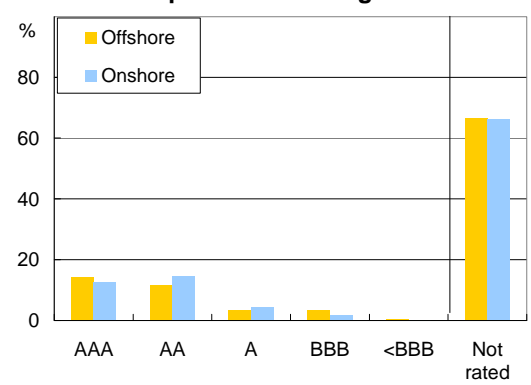

Korea: credit rating

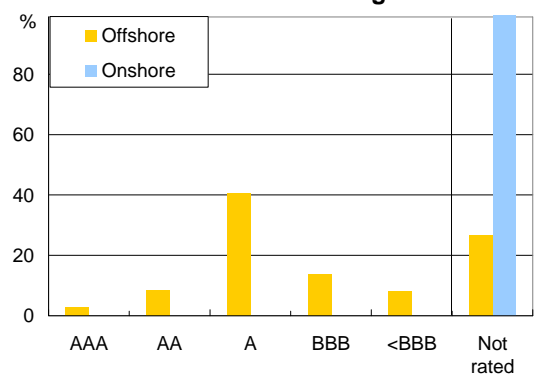

Singapore: credit rating

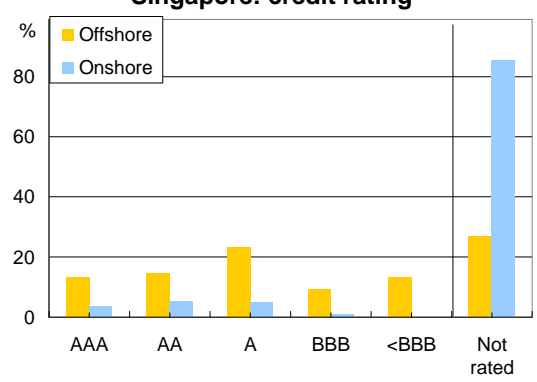

Australia: credit rating

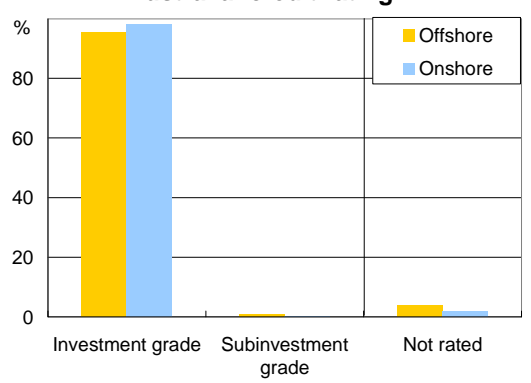

Hong Kong: credit rating

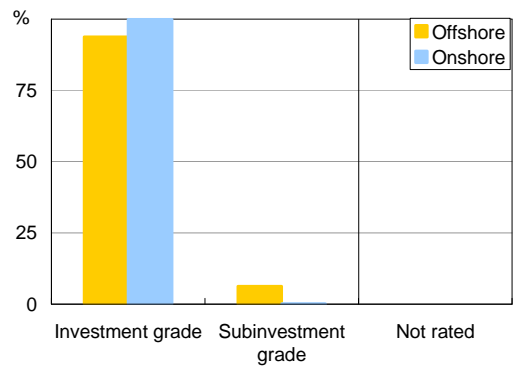

Japan: credit rating

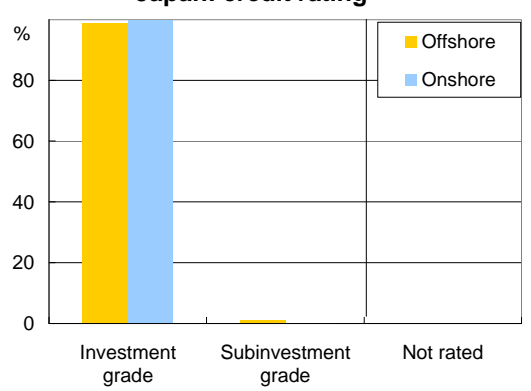

Korea: credit rating

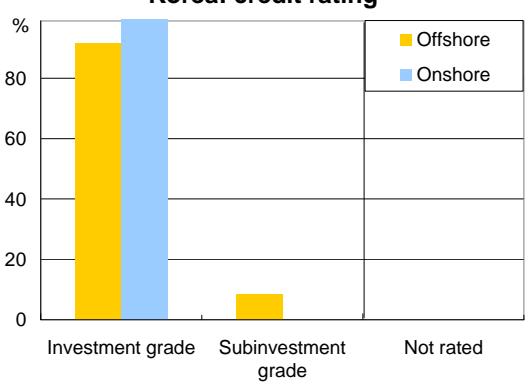

Singapore: credit rating

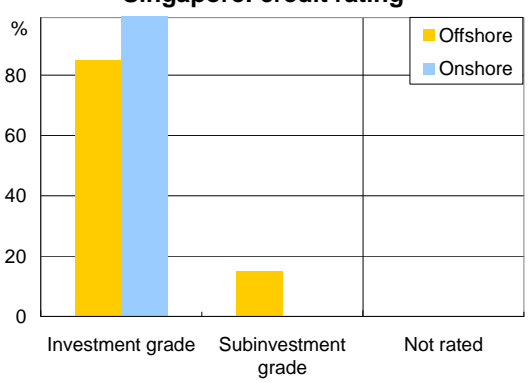


Australia: credit rating

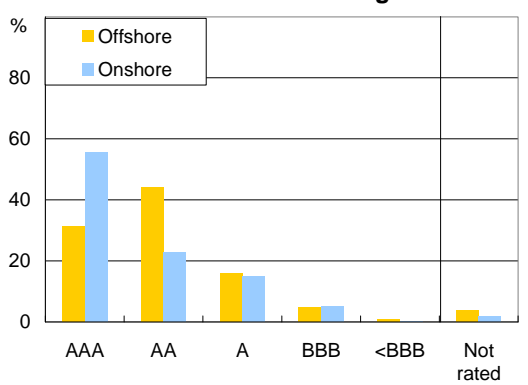

Hong Kong: credit rating

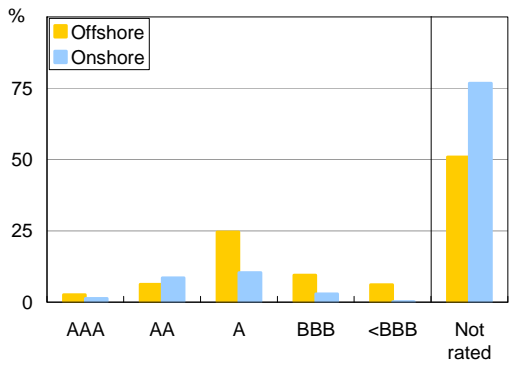

Japan: credit rating

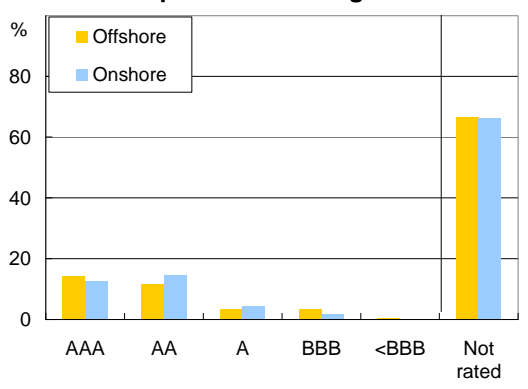

Korea: credit rating

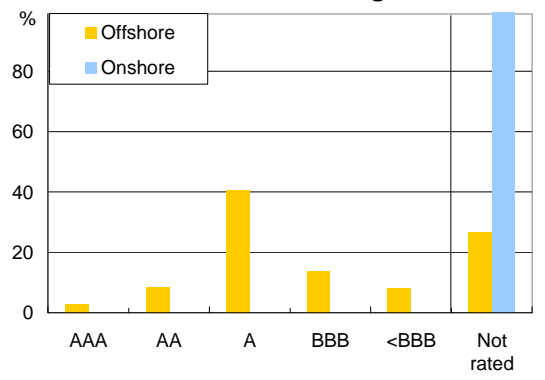

Singapore: credit rating

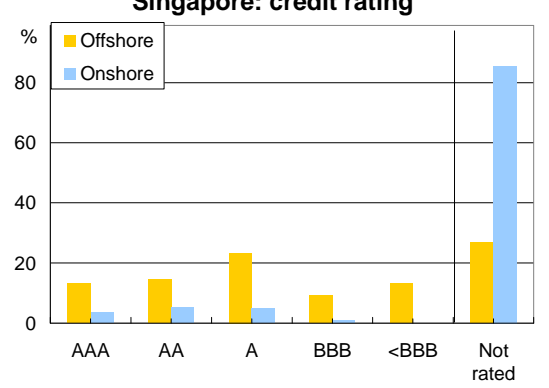

Australia: credit rating

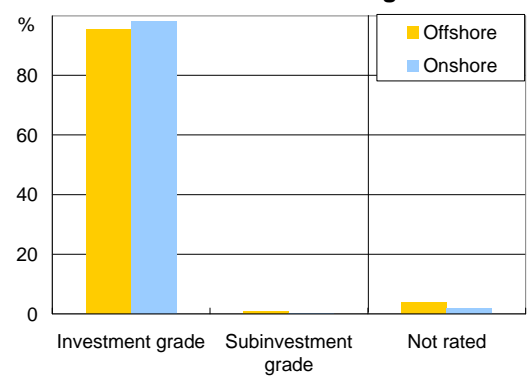

Hong Kong: credit rating

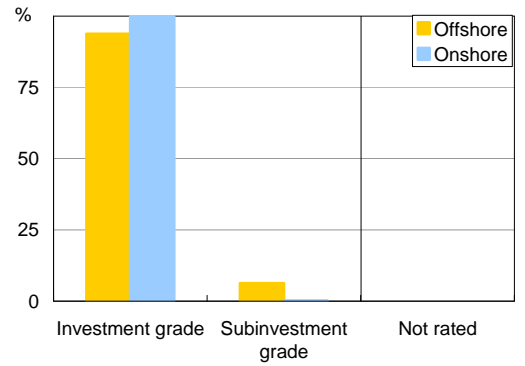

Japan: credit rating

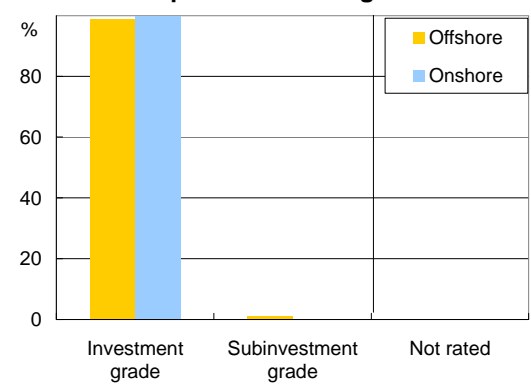

Korea: credit rating

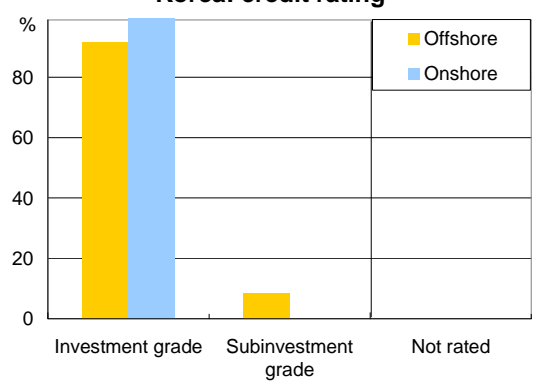

Singapore: credit rating

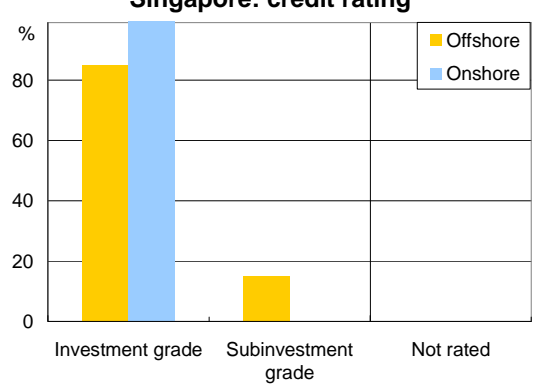


Figure 5

Australia major banks: covered bargain

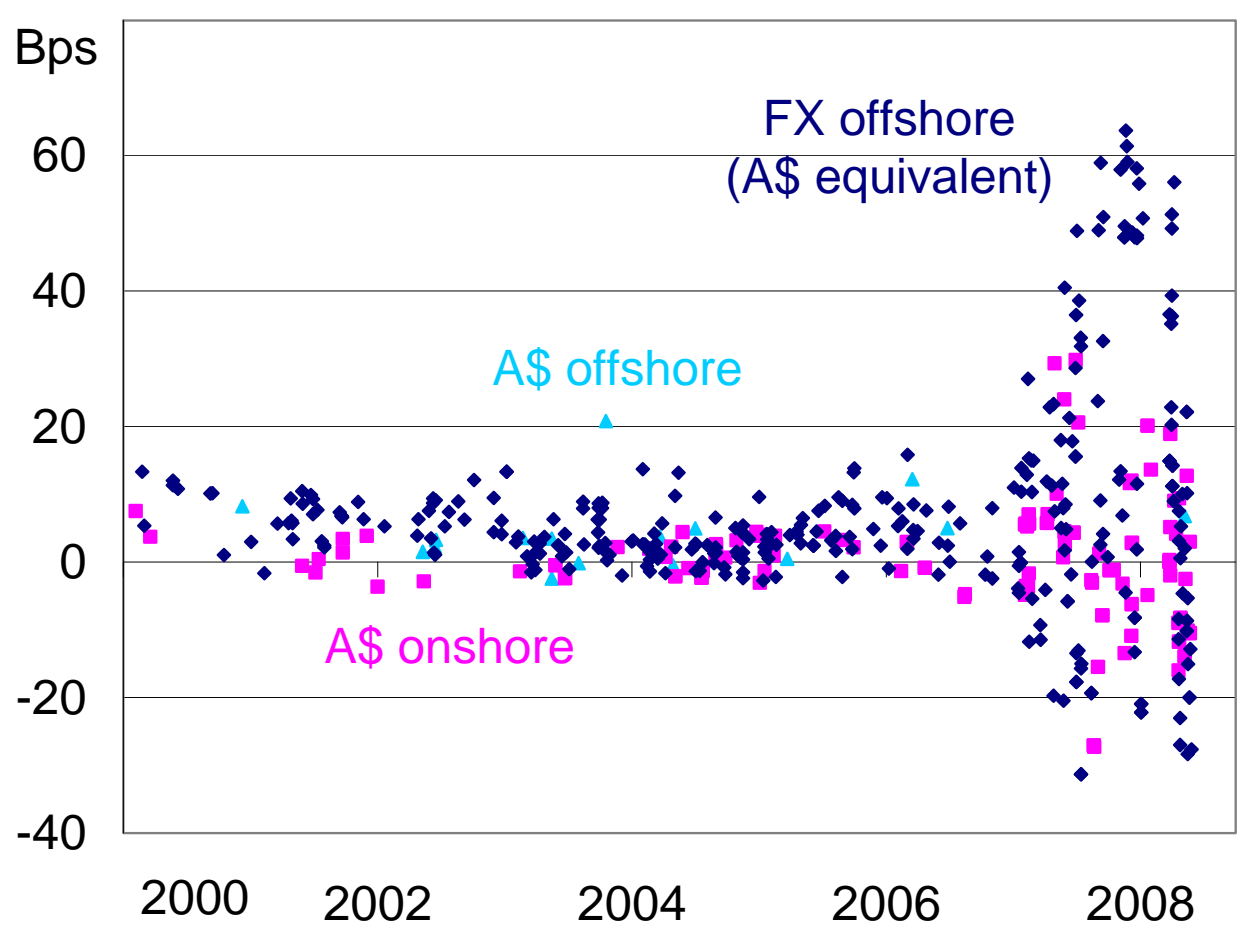

Figure 6

Major banks' bond pricing at issuance

\$A equivalent spread to CGS*

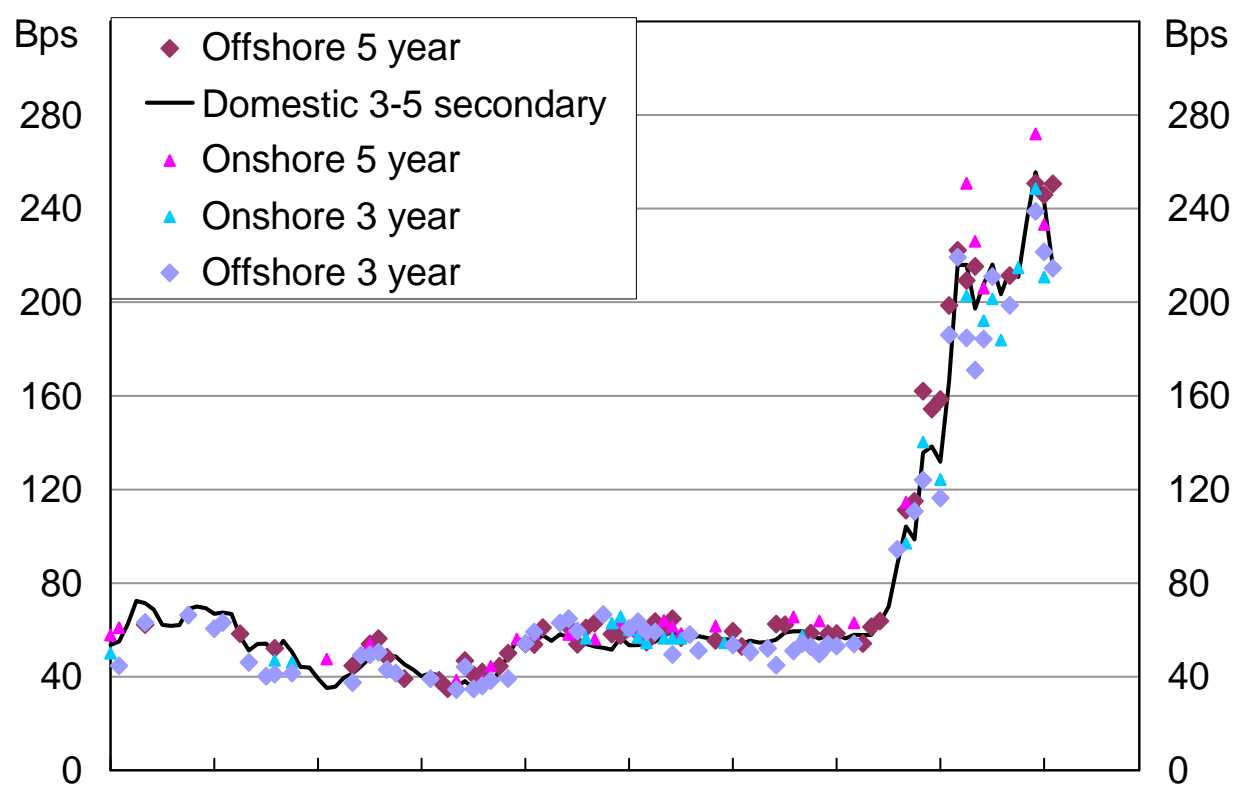

2000200120022003200420052006200720082009

* Includes fee for guaranteed bonds.

Includes AUD, USD, Euro, GBP, CHF and JPY

Source: RBA 
Table 1

Outstanding bonds issued by Asia-Pacific residents

End-2007, per cent of GDP

\begin{tabular}{|c|c|c|c|c|c|}
\hline & \multicolumn{2}{|c|}{ Onshore } & \multicolumn{2}{|c|}{ Offshore } & \multirow{2}{*}{$\begin{array}{c}\begin{array}{c}\text { Offshore } \\
\text { share }\end{array} \\
\text { (Per cent) } \\
=(c+d) /(a+b)\end{array}$} \\
\hline & $\begin{array}{c}\text { Government } \\
\text { (a) }\end{array}$ & $\begin{array}{c}\text { Corporate } \\
\text { (b) }\end{array}$ & $\begin{array}{l}\text { Local } \\
\text { currency } \\
\text { (c) }\end{array}$ & $\begin{array}{l}\text { Foreign } \\
\text { currency } \\
\text { (d) }\end{array}$ & \\
\hline Australia & 13 & 63 & 9 & 44 & 41 \\
\hline China & 35 & 17 & 0 & 1 & 1 \\
\hline Hong Kong & 9 & 16 & 6 & 18 & 49 \\
\hline Indonesia & 18 & 2 & 0 & 2 & 11 \\
\hline India & 38 & 4 & 0 & 3 & 6 \\
\hline Japan & 163 & 39 & 2 & 1 & 2 \\
\hline Korea & 49 & 64 & 0 & 11 & 9 \\
\hline Malaysia & 38 & 58 & 0 & 13 & 12 \\
\hline New Zealand & 18 & $N / A$ & 1 & 14 & 45 \\
\hline Philippines & 35 & 2 & 0 & 23 & 38 \\
\hline Singapore & 42 & 18 & 6 & 29 & 36 \\
\hline Thailand & 39 & 18 & 0 & 3 & 5 \\
\hline
\end{tabular}


Table 2

Global market for bonds denominated in Asia-Pacific currencies

Outstanding, end-2007, per cent of GDP

\begin{tabular}{|c|c|c|c|c|c|}
\hline & \multicolumn{2}{|c|}{ Onshore } & \multicolumn{2}{|c|}{ Offshore } & \multirow{2}{*}{$\begin{array}{l}\text { Non- } \\
\text { resident } \\
\text { offshore } \\
\text { share }\end{array}$} \\
\hline & Resident & $\begin{array}{l}\text { Non- } \\
\text { resident } \\
\text { (a) }\end{array}$ & Resident & $\begin{array}{l}\begin{array}{l}\text { Non- } \\
\text { resident }\end{array} \\
\text { (b) }\end{array}$ & \\
\hline Australian dollar & 76 & 8.5 & 9 & 9.4 & 53 \\
\hline Chinese renminbi & 52 & 0.0 & 0 & 0.1 & 100 \\
\hline Hong Kong dollar & 25 & 2.1 & 6 & 32.6 & 94 \\
\hline Indonesian rupiah & 20 & 0.0 & 0 & 0.3 & 100 \\
\hline Indian rupee & 42 & 0.0 & 0 & 0.0 & $\mathrm{n} / \mathrm{a}$ \\
\hline Japanese yen & 202 & 1.6 & 2 & 10.1 & 86 \\
\hline Korean won & 113 & 0.0 & 0 & 0.1 & 100 \\
\hline Malaysian ringgit & 96 & 0.3 & 0 & 0.5 & 63 \\
\hline New Zealand dollar & 18 & 3.5 & 1 & 39.8 & 92 \\
\hline Philippine peso & 38 & 0.1 & 0 & 0.1 & 50 \\
\hline Singapore dollar & 61 & 2.3 & 6 & 9.5 & 81 \\
\hline Thai baht & 57 & 0.3 & 0 & 0.1 & 25 \\
\hline
\end{tabular}

Source: BIS. 
Table 3

Univariate probit estimates

\begin{tabular}{|c|c|c|c|c|c|c|}
\hline & & Australia & Hong Kong & Japan & Korea & Singapore \\
\hline \multirow[t]{4}{*}{$\log ($ Size $)$} & Coefficient & 0.0685 & 0.3410 & -0.4786 & 0.6130 & 0.3338 \\
\hline & $\mathrm{z}$ & 7.45 ** & 17.77 ** & $-74.82 * \star$ & 40.64 ** & 10.42 ** \\
\hline & Pseudo Rsq & 0.01 & 0.07 & 0.10 & 0.28 & 0.08 \\
\hline & No obs & 6,795 & 3,757 & 17,706 & 19,946 & 1,191 \\
\hline \multirow[t]{4}{*}{$\log$ (Tenor) } & Coefficient & 0.069 & 0.362 & 0.416 & 0.195 & 0.235 \\
\hline & z & 8.11 ** & 12.33 ** & 35.03 ** & 6.94 ** & $4.68^{* *}$ \\
\hline & Pseudo Rsq & 0.01 & 0.03 & 0.05 & 0.01 & 0.02 \\
\hline & No obs & 6,786 & 3,572 & 17,702 & 20,114 & 1,192 \\
\hline \multirow[t]{4}{*}{ Rating Index } & Coefficient & 0.063 & 0.053 & 0.017 & $3 /$ & 0.133 \\
\hline & z & 9.07 ** & 3.59 ** & 1.61 & & 3.75 ** \\
\hline & Pseudo Rsq & 0.01 & 0.01 & 0.00 & & 0.07 \\
\hline & No obs & 5,939 & 1,160 & 2,142 & & 187 \\
\hline \multirow[t]{4}{*}{ Sub-inv Grade } & Coefficient & $1 /$ & 1.82 & 0.63 & $1 /$ & $1 /$ \\
\hline & z & & 7.87 ** & 3.46 ** & & \\
\hline & Pseudo Rsq & & 0.02 & 0.00 & & \\
\hline & No obs & & 3,846 & 9,983 & & \\
\hline \multirow[t]{4}{*}{ Fixed } & Coefficient & 0.76 & 0.03 & -1.04 & -1.43 & -0.62 \\
\hline & $\mathrm{z}$ & 20.37 ** & 0.67 & -20.85 ** & -25.45 ** & -5.04 ** \\
\hline & Pseudo Rsq & 0.06 & 0.00 & 0.05 & 0.17 & 0.04 \\
\hline & No obs & 5,286 & 3,452 & 11,519 & 5,935 & 583 \\
\hline \multirow[t]{4}{*}{ CA/GDP } & Coefficient & -0.110 & 0.044 & 0.223 & 0.007 & 0.028 \\
\hline & $\mathrm{z}$ & -9.8 ** & $8.7 * *$ & 23.43 ** & 1.65 & 4.21 ** \\
\hline & Pseudo Rsq & 0.01 & 0.02 & 0.02 & 0.00 & 0.01 \\
\hline & No obs & 6,799 & 2,768 & 17,706 & 20,114 & 1,192 \\
\hline \multirow[t]{4}{*}{ CIP } & Coefficient & 27.590 & $0.0496 \quad 2 /$ & -1.700 & 1.371 & 1.100 \\
\hline & z & $20.85 * *$ & 0.8 & $-6.23 * \star$ & 14.78 ** & 4.11 ** \\
\hline & Pseudo Rsq & 0.60 & 0.00 & 0.00 & 0.20 & 0.02 \\
\hline & No obs & 6,563 & 2,607 & 14,581 & 1,220 & 937 \\
\hline \multirow[t]{4}{*}{$\mathrm{i}-\mathrm{i}^{\mathrm{H}}$} & Coefficient & -2.005 & -0.0482 & 0.2903 & -0.9977 & 0.2373 \\
\hline & z & -30.34 & -1.81 & $16.4^{* *}$ & -35.9 ** & 6.94 ** \\
\hline & Pseudo Rsq & 0.50 & 0.00 & 0.02 & 0.51 & 0.04 \\
\hline & No obs & 6,799 & 3,746 & 17,349 & 19,998 & 1,168 \\
\hline \multirow[t]{4}{*}{ year } & Coefficient & 0.039 & 0.014 & 0.020 & 0.084 & -0.006 \\
\hline & $\mathrm{z}$ & 11.22 ** & 3.04 ** & $9.93 * *$ & 26.08 ** & -0.58 \\
\hline & Pseudo Rsq & 0.01 & 0.00 & 0.00 & 0.08 & 0.00 \\
\hline & No obs & 6,799 & 3,846 & 17,706 & 20,114 & 1,192 \\
\hline \multirow[t]{4}{*}{ Market Size } & Coefficient & 0.436 & 0.041 & 0.010 & 0.055 & 0.053 \\
\hline & z & 16.91 ** & 15.11 ** & 14.44 & 30.79 ** & 9.05 ** \\
\hline & Pseudo Rsq & 0.66 & 0.36 & 0.01 & 0.63 & 0.45 \\
\hline & No obs & 6,798 & 3,801 & 17,396 & 20,040 & 1,185 \\
\hline
\end{tabular}

Note: ** indicates significance to the 1\% level; * indicates significance to the $5 \%$ level.

Dependent variable is 1 if the bond is issued offshore and 0 is issued onshore.

$\mathrm{z}$ :

The pseudo $\mathrm{R}^{2}$ measures the improvement of the regression fit against a regression on a constant only.

$1 /$ Sub-investment grade bonds only issued offshore.

2/ HK pricing constructed from sovereign index (no corporate index), so potentially large measurement error.

3/ Ratings only available for offshore bonds. 
Table 4

Multivariate probit estimates with bond characteristics

\begin{tabular}{|c|c|c|c|c|c|c|c|c|}
\hline & \multicolumn{2}{|c|}{ Australia } & \multicolumn{2}{|c|}{ Hong Kong } & \multicolumn{2}{|c|}{ Japan } & \multirow{2}{*}{$\begin{array}{r}\text { Korea } \\
(7)\end{array}$} & \multirow{2}{*}{$\begin{array}{c}\text { Singapore } \\
(8)\end{array}$} \\
\hline & (1) & (2) & (3) & (4) & (5) & (6) & & \\
\hline \multirow[t]{2}{*}{$\log ($ Size) } & -0.074 & -0.055 & 0.261 & 0.299 & -0.293 & -0.095 & 0.467 & 0.342 \\
\hline & -2.67 * & -1.87 & 5.91 ** & 9.88 ** & $-5.14 * \star$ & $-2.21 *$ & 3.77 ** & 3.89 ** \\
\hline \multirow[t]{2}{*}{$\log$ (Tenor) } & -0.13 & -0.14 & 0.36 & 0.32 & 0.487 & 0.71 & 0.50 & -0.02 \\
\hline & -2.38 * & $-2.55 *$ & $6.05 * \star$ & 8.08 ** & 3.73 ** & 7.32 ** & 1.87 & -0.1 \\
\hline \multirow[t]{2}{*}{ Rating Index } & -0.041 & -- & -0.022 & -- & -0.148 & -- & $3 /$ & 21 \\
\hline & $-2.82 * \star$ & & -1.13 & & -5.65 & & & \\
\hline \multirow{2}{*}{$\begin{array}{l}\text { Sub-investment } \\
\text { grade }\end{array}$} & -- & $1 /$ & -- & 1.32 & -- & 1.54 & $3 /$ & $1 /$ \\
\hline & & & & 3.50 ** & & 3.44 ** & & \\
\hline \multirow[t]{2}{*}{ Fixed } & 1.02 & 1.01 & 0.28 & 0.29 & -1.029 & -1.38 & -0.11 & -1.15 \\
\hline & 14.23 ** & 14.15 ** & 2.61 * & 4.56 ** & -5.52 ** & -10.27 ** & -0.50 & -4.93 ** \\
\hline \multirow[t]{2}{*}{ CA/GDP } & -0.064 & -0.054 & 0.023 & 0.032 & 0.148 & -0.039 & -0.060 & -0.017 \\
\hline & $-2.25 *$ & -1.94 & 2.13 * & 4.11 ** & 1.49 * & -0.57 & -1.19 & -0.62 \\
\hline \multirow[t]{2}{*}{ CIP } & 58.7 & 56.7 & 0.49 & 0.13 & $4 /$ & $4 /$ & 0.501 & -0.70 \\
\hline & 8.14 ** & 7.95 ** & $2.52 *$ & 1.37 & & & 1.87 & -0.92 \\
\hline \multirow[t]{2}{*}{$i^{\prime}-i^{H}$} & -1.31 & -1.27 & 0.57 & 0.64 & $5 /$ & 5/ & -0.56 & 1.14 \\
\hline & -6.42 ** & $-6.31 * *$ & 4.9 ** & 8.68 ** & & & $-5.22 * *$ & 3.78 ** \\
\hline \multirow[t]{2}{*}{ year } & 0.051 & 0.052 & -0.0286 & -0.012 & -0.186 & -0.062 & -0.272 & 0.140 \\
\hline & 4.67 ** & 4.74 ** & -1.28 & -0.66 & -4.15 ** & -2.18 ** & -1.33 & 1.69 \\
\hline No obs. & 4,498 & 4,487 & 953 & 2,603 & 646 & 2,594 & 807 & 426 \\
\hline Pseudo Rsq & 0.74 & 0.74 & 0.11 & 0.27 & 0.33 & 0.28 & 0.55 & 0.43 \\
\hline
\end{tabular}

Notes: Dependent variable is 1 if the bond is issued offshore and 0 is issued onshore.

** indicates significance to the $1 \%$ level; * indicates significance to the $5 \%$ level

The pseudo $\mathrm{R}^{2}$ measures the improvement of the regression fit against a regression on a constant only.

$1 /$ Sub-investment grade bonds only issued offshore.

2/ Small sample.

3/ Ratings only for offshore bonds.

4/ Dropped because of collinearity

5/ i_diff $>0$ predicts offshore perfectly for the available sample 
Table 5

Multivariate probit estimates with market size

\begin{tabular}{|c|c|c|c|c|c|}
\hline & Australia & Hong Kong & Japan & Korea & Singapore \\
\hline \multirow[t]{2}{*}{ Market size } & 0.343 & 21 & 0.0727 & 0.043 & 0.1237 \\
\hline & 6.05 ** & & 19.26 ** & 14.81 ** & 0.44 \\
\hline \multirow[t]{2}{*}{ CA/GDP } & -0.0077 & -0.000341 & 0.153 & -0.126 & 0.025 \\
\hline & -0.37 & -0.06 & 10.53 & -2.2 * & 1.24 \\
\hline \multirow[t]{2}{*}{ CIP } & 21.92 & 0.816008 & 14 & -2.35 & 1.025 \\
\hline & 1.11 & 11.59 ** & & -6.66 ** & 0.02 \\
\hline \multirow[t]{2}{*}{ i_diff } & 0.4049 & 0.151004 & 15 & -1.43 & -1.38 \\
\hline & 0.66 & $6.67^{\text {** }}$ & & -10.76 ** & -0.09 \\
\hline \multirow[t]{2}{*}{ year } & -0.050 & 0.124485 & 0.1294 & -0.68 & -0.002 \\
\hline & $-8.42^{* *}$ & 11.42 ** & 26.87 & -3.59 ** & -0.05 \\
\hline No obs. & 0.6563 & 3870 & 14336 & 1199 & 935 \\
\hline pseudo Rsq & 0.66 & 0.17 & 0.09 & 0.79 & 0.74 \\
\hline
\end{tabular}

Notes: Dependent variable is 1 if the bond is issued offshore and 0 is issued onshore.

** indicates significance to the $1 \%$ level; * indicates significance to the $5 \%$ level

The pseudo $\mathrm{R}^{2}$ measures the improvement of the regression fit against a regression on a constant only.

2/ Market size $>0.48$ predicts offshore perfectly

4/ Dropped because of collinearity

5/ i_diff $>0$ predicts offshore perfectly for the available sample 
Table 6

More accurate pricing data (Australian major banks)

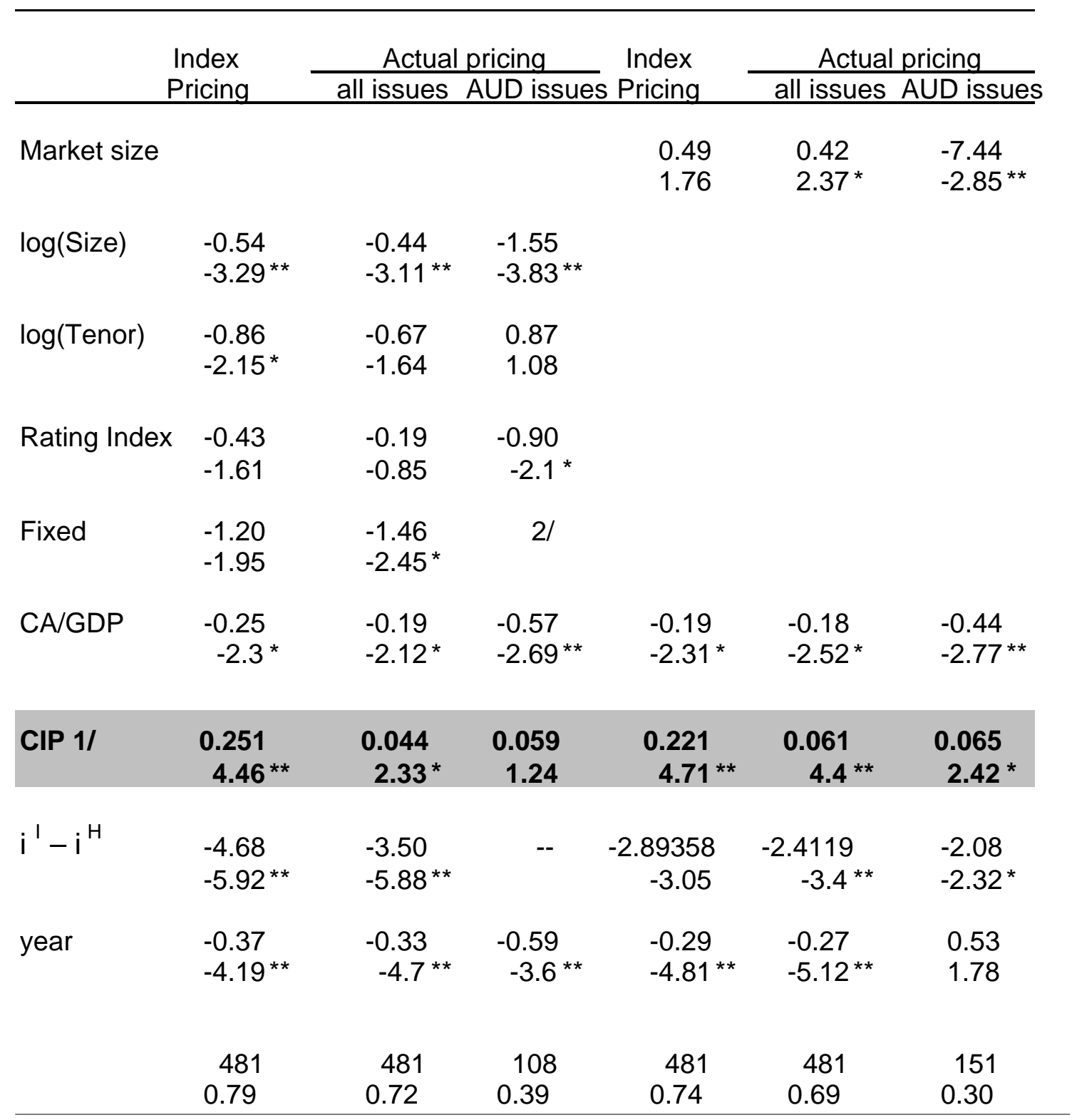

$1 /$ Index pricing based on AA indices. Actual pricing based on actual bond price relative to AUD secondary market price.

2/ AUD floating rate bonds issued only onshore.

Note: 2000-2009 period. 
Table 7

Crisis dummy and other factors

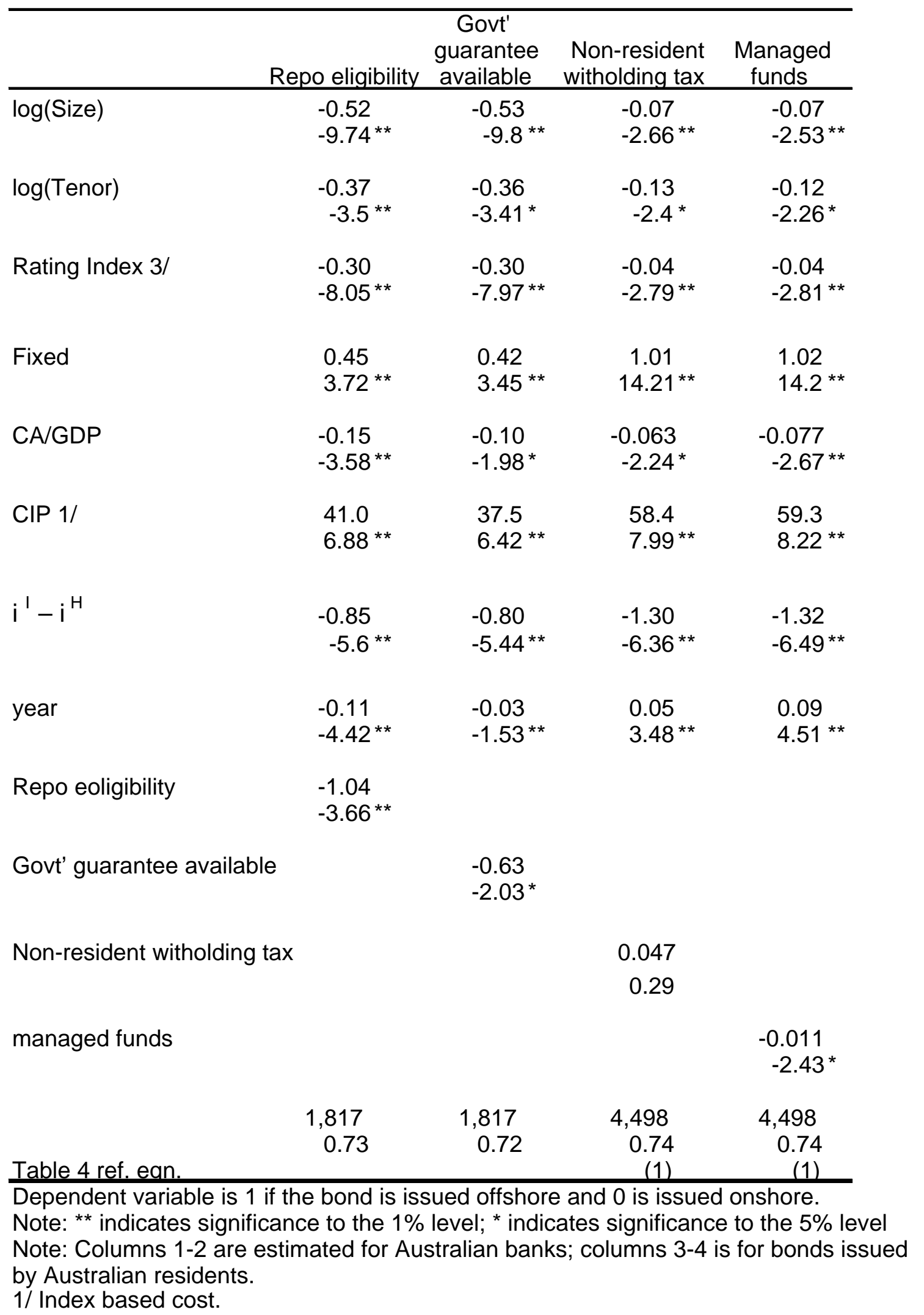


Table 8

Effect of the international financial crisis

\begin{tabular}{|c|c|c|c|c|c|}
\hline & \multicolumn{5}{|c|}{ Crisis dummy } \\
\hline & Australia & Hong Kong & Japan & Singapore & Korea \\
\hline$\overline{\log (\text { Size })}$ & $\begin{array}{l}-0.07 \\
-2.67 \text { ** }\end{array}$ & $\begin{array}{l}0.30 \\
9.97^{* *}\end{array}$ & $\begin{array}{l}-0.10 \\
-2.26 \text { * }\end{array}$ & $\begin{array}{l}0.34 \\
3.89 * \star\end{array}$ & $\begin{array}{l}0.47 \\
3.78 \text { ** }\end{array}$ \\
\hline $\log$ (Tenor) & $\begin{array}{l}-0.13 \\
-2.38^{*}\end{array}$ & $\begin{array}{l}0.32 \\
8.04 \text { ** }\end{array}$ & $\begin{array}{l}0.71 \\
7.28 \text { ** }\end{array}$ & $\begin{array}{r}-0.02 \\
-0.1\end{array}$ & $\begin{array}{l}0.50 \\
1.86\end{array}$ \\
\hline Rating Index $3 /$ & $\begin{array}{l}-0.04 \\
-2.8 \text { ** }\end{array}$ & $\begin{array}{l}1.26 \\
3.36 \text { ** }\end{array}$ & $\begin{array}{l}1.48 \\
3.3 \text { ** }\end{array}$ & $4 /$ & \\
\hline Fixed & $\begin{array}{c}1.02 \\
14.12^{\text {** }}\end{array}$ & $\begin{array}{l}0.27 \\
4.17 \text { ** }\end{array}$ & $\begin{array}{l}-1.41 \\
-10.37^{\star *}\end{array}$ & $\begin{array}{l}-1.15 \\
-4.9\end{array}$ & $\begin{array}{l}-0.12 \\
-0.55\end{array}$ \\
\hline CA/GDP & $\begin{array}{c}-0.063 \\
-2.13^{*}\end{array}$ & $\begin{array}{l}0.017 \\
2.07 \text { * }\end{array}$ & $\begin{array}{r}-0.023 \\
-0.34\end{array}$ & $\begin{array}{r}-0.018 \\
-0.62\end{array}$ & $\begin{array}{r}-0.062 \\
-1.21\end{array}$ \\
\hline CIP 1/ & $\begin{array}{l}58.7 \\
8.12 \text { ** }\end{array}$ & $\begin{array}{r}0.0 \\
-0.25\end{array}$ & $6 /$ & $\begin{array}{r}-0.7 \\
-0.92\end{array}$ & $\begin{array}{r}0.5 \\
1.77\end{array}$ \\
\hline $\mathrm{i}^{\mathrm{I}}-\mathrm{i}^{\mathrm{H}}$ & $\begin{array}{l}-1.31 \\
-6.4 \text { ** }\end{array}$ & $\begin{array}{l}0.67 \\
9.07 \text { ** }\end{array}$ & $5 /$ & $\begin{array}{l}1.14 \\
3.78 \text { ** }\end{array}$ & $\begin{array}{l}-0.56 \\
-5.22^{\text {** }}\end{array}$ \\
\hline year & $\begin{array}{l}0.05 \\
3.83 \text { ** }\end{array}$ & $\begin{array}{l}0.07 \\
3.51 \text { ** }\end{array}$ & $\begin{array}{l}-0.12 \\
-3.31 \text { ** }\end{array}$ & $\begin{array}{r}0.14 \\
1.6\end{array}$ & $\begin{array}{l}-0.34 \\
-1.21\end{array}$ \\
\hline crisis dummy & $\begin{array}{l}-0.01 \\
-0.09\end{array}$ & $\begin{array}{l}-0.80 \\
-6.76^{\text {** }}\end{array}$ & $\begin{array}{l}0.46 \\
2.45\end{array}$ & $\begin{array}{r}-0.09 \\
-0.1\end{array}$ & $\begin{array}{l}0.14 \\
0.38\end{array}$ \\
\hline & $\begin{array}{r}4,498 \\
0.74\end{array}$ & $\begin{array}{r}2,317 \\
0.16\end{array}$ & $\begin{array}{r}2,594 \\
0.29\end{array}$ & $\begin{array}{l}446 \\
0.46\end{array}$ & $\begin{array}{l}807 \\
0.56\end{array}$ \\
\hline Table 4 ref. eqn. & (1) & (4) & (6) & (7) & (8) \\
\hline
\end{tabular}

Dependent variable is 1 if the bond is issued offshore and 0 is issued onshore.

Note: ** indicates significance to the $1 \%$ level; * indicates significance to the $5 \%$ level $1 /$ Actual cost relative to AUD secondary market.

2/ This result (onshore but insignificant shift from govt guarantee) holds if estimated for major bank subsample.

3/ Rating index for Australia, sub-investment grade dummy for other countries.

4/ Sub-investment grade issuance only offshore.

5/ Foreign currency interest rates all higher than domestic interest rates.

6/ Dropped because of collinearity 
Table 9

Sectoral estimates: financial institutions

\begin{tabular}{|c|c|c|c|c|c|}
\hline & Australia & Hong Kong & Japan & Korea & Singapore \\
\hline $\log ($ Size $)$ & $\begin{array}{l}-0.08 \\
-2.66 \text { ** }\end{array}$ & $\begin{array}{l}0.28 \\
8.65^{\star \star}\end{array}$ & $\begin{array}{l}-0.15 \\
-2.88\end{array}$ & $\begin{array}{l}0.92 \\
3.02 \text { ** }\end{array}$ & $\begin{array}{l}0.38 \\
3.28 \text { ** }\end{array}$ \\
\hline $\log ($ Tenor) & $\begin{array}{l}-0.15 \\
-2.47\end{array}$ & $\begin{array}{l}0.277 \\
6.64 \text { ** }\end{array}$ & $\begin{array}{l}0.9278 \\
7.79 \text { ** }\end{array}$ & $\begin{array}{r}0.408 \\
0.71\end{array}$ & $\begin{array}{r}0.0145 \\
0.06\end{array}$ \\
\hline Rating Index & $\begin{array}{l}-0.057 \\
-3.44 \text { ** }\end{array}$ & -- & -- & -- & -- \\
\hline Sub-investment grade & -- & $\begin{array}{l}1.13 \\
2.59 *\end{array}$ & $\begin{array}{l}1.016 \\
2.16 \text { ** }\end{array}$ & $2 /$ & $1 /$ \\
\hline Fixed & $\begin{array}{c}1.22 \\
15.79\end{array}$ & $\begin{array}{l}0.28 \\
4.25 \text { ** }\end{array}$ & $\begin{array}{l}-0.66 \\
-4.18^{\star \star}\end{array}$ & $\begin{array}{l}-0.87 \\
-1.55\end{array}$ & $\begin{array}{l}-0.764 \\
-2.12^{*}\end{array}$ \\
\hline CA/GDP & $\begin{array}{l}-0.07 \\
-2.32\end{array}$ & $\begin{array}{l}0.03 \\
3.93^{* \star}\end{array}$ & $\begin{array}{r}-0.0049 \\
-0.05\end{array}$ & $\begin{array}{r}-0.015 \\
-0.13\end{array}$ & $\begin{array}{l}-0.03 \\
-0.87\end{array}$ \\
\hline CIP & $\begin{array}{l}50.7 \\
7.74 \text { ** }\end{array}$ & $\begin{array}{r}0.1 \\
1.27\end{array}$ & $4 /$ & $\begin{array}{l}2.03 \\
2.8 \text { ** }\end{array}$ & $\begin{array}{l}-3.07 \\
-2.12^{*}\end{array}$ \\
\hline $\mathrm{i}^{\mathrm{I}}-\mathrm{i}^{\mathrm{H}}$ & $\begin{array}{l}-1.137 \\
-6.18 \text { ** }\end{array}$ & $\begin{array}{l}0.664 \\
8.43^{* *}\end{array}$ & $5 /$ & $\begin{array}{l}-0.436 \\
-2.26\end{array}$ & $\begin{array}{l}1.999 \\
2.4^{*}\end{array}$ \\
\hline year & $\begin{array}{l}0.047 \\
4.14 \text { ** }\end{array}$ & $\begin{array}{r}0.002 \\
0.11\end{array}$ & $\begin{array}{l}-0.081 \\
-2.16\end{array}$ & $\begin{array}{l}-0.32 \\
-0.75\end{array}$ & $\begin{array}{r}0.176 \\
1.47\end{array}$ \\
\hline $\begin{array}{l}\text { No obs. } \\
\text { Pseudo Rsq }\end{array}$ & $\begin{array}{l}3923 \\
0.74\end{array}$ & $\begin{array}{l}2167 \\
0.11\end{array}$ & $\begin{array}{r}725 \\
0.26\end{array}$ & $\begin{array}{l}313 \\
0.76\end{array}$ & $\begin{array}{l}156 \\
0.46\end{array}$ \\
\hline \multicolumn{6}{|c|}{$\begin{array}{l}\text { Notes: Dependent variable is } 1 \text { if the bond is issued offshore and } 0 \text { is issued onshore. } \\
\text { ** indicates significance to the } 1 \% \text { level; * indicates significance to the } 5 \% \text { level }\end{array}$} \\
\hline \multicolumn{6}{|c|}{$\begin{array}{l}\text { The pseudo } \mathrm{R}^{2} \text { measures the improvement of the regression fit against a regression } \\
\text { on a constant only. }\end{array}$} \\
\hline \multicolumn{6}{|c|}{$\begin{array}{l}\text { /1 Sub-investment grade bonds only issued offshore. } \\
\text { 2/ Small sample. } \\
\text { 3/ Ratings only for offshore bonds. } \\
\text { 4/ Dropped because of collinearity } \\
\text { 5/ i_diff }>0 \text { predicts offshore perfectly in the sample }\end{array}$} \\
\hline
\end{tabular}


Table 10

Sectoral estimates: nonfinancial corporates

\begin{tabular}{|c|c|c|c|c|c|}
\hline & Australia & Hong Kong & Japan & Korea & Singapore \\
\hline$\overline{\log (\text { Size })}$ & $\begin{array}{l}0.28 \\
1.55\end{array}$ & $\begin{array}{l}0.09 \\
0.66 \text { ** }\end{array}$ & $\begin{array}{l}1.46 \\
1.56\end{array}$ & $\begin{array}{l}0.30 \\
1.98 *\end{array}$ & $\begin{array}{l}0.37 \\
1.05\end{array}$ \\
\hline $\log$ (Tenor) & $\begin{array}{l}0.71 \\
2.57 \text { * }\end{array}$ & $\begin{array}{l}0.55 \\
2.23^{*}\end{array}$ & $\begin{array}{r}-0.038 \\
-0.04\end{array}$ & $\begin{array}{l}0.719 \\
2.12^{*}\end{array}$ & $\begin{array}{r}-0.2477 \\
-0.44\end{array}$ \\
\hline Rating Index & $\begin{array}{l}0.197 \\
3.55 \text { ** }\end{array}$ & -- & -- & -- & -- \\
\hline Sub-investment grade & -- & $1 /$ & $4 /$ & $2 /$ & $1 /$ \\
\hline Fixed & $\begin{array}{l}-0.57 \\
-1.84\end{array}$ & $\begin{array}{r}0.04 \\
0.1\end{array}$ & $3 /$ & $\begin{array}{l}0.05 \\
0.18\end{array}$ & $\begin{array}{l}-1.299 \\
-1.76^{\star}\end{array}$ \\
\hline CA/GDP & $\begin{array}{r}-0.095 \\
-0.70\end{array}$ & $\begin{array}{r}0.047 \\
1.24\end{array}$ & $\begin{array}{r}-1.277 \\
-1.00\end{array}$ & $\begin{array}{r}-0.113 \\
-1.90\end{array}$ & $\begin{array}{r}0.113 \\
1.00\end{array}$ \\
\hline CIP & $1 /$ & $\begin{array}{r}0.047 \\
1.24\end{array}$ & $4 /$ & $\begin{array}{r}0.257 \\
0.75\end{array}$ & $4 /$ \\
\hline$i^{\prime}-i^{H}$ & $2 /$ & $\begin{array}{r}0.386 \\
1.54\end{array}$ & $/ 5$ & $\begin{array}{r}-0.5766 \\
-3.7^{* *}\end{array}$ & $4 /$ \\
\hline year & $\begin{array}{r}-0.006 \\
-0.1\end{array}$ & $\begin{array}{r}-0.138 \\
-2.32\end{array}$ & $\begin{array}{l}-0.081 \\
-2.16^{*}\end{array}$ & $\begin{array}{l}-0.13 \\
-0.51\end{array}$ & $\begin{array}{r}0.031 \\
0.12\end{array}$ \\
\hline $\begin{array}{l}\text { No obs. } \\
\text { Pseudo Rsq }\end{array}$ & $\begin{array}{c}432 \\
0.21\end{array}$ & $\begin{array}{l}123 \\
0.14\end{array}$ & $\begin{array}{r}21 \\
0.37\end{array}$ & $\begin{array}{l}495 \\
0.45\end{array}$ & $\begin{array}{l}290 \\
0.78\end{array}$ \\
\hline \multicolumn{6}{|c|}{$\begin{array}{l}\text { Notes: Dependent variable is } 1 \text { if the bond is issued offshore and } 0 \text { is issued onshore. } \\
* * \text { indicates significance to the } 1 \% \text { level; * indicates significance to the } 5 \% \text { level }\end{array}$} \\
\hline \multicolumn{6}{|c|}{$\begin{array}{l}\text { The pseudo } \mathrm{R}^{2} \text { measures the improvement of the regression } \\
\text { constant only. } \\
\text { /1 Sub-investment grade bonds only issued offshore. } \\
\text { 2/ Only offshore rating in dataset. } \\
3 \text { / Only fixed rate bonds issued onshore in the sample. } \\
\text { 4/ Dropped because of collinearity. } \\
\text { 5/ i_diff predicts success perfectly for the available sample. }\end{array}$} \\
\hline
\end{tabular}


Table 11

Detailed sectoral estimates: Australian data

\begin{tabular}{|c|c|c|c|c|c|c|}
\hline & All & Corporate & $\begin{array}{l}\text { Non-bank } \\
\text { financials }\end{array}$ & Bank & $\begin{array}{l}\text { Major } \\
\text { Banks }\end{array}$ & $\begin{array}{c}\mathrm{ABS} \\
3 /\end{array}$ \\
\hline \multirow{2}{*}{$\log ($ Size) } & -0.074 & 0.280 & -0.062 & -0.534 & -0.462 & 0.054 \\
\hline & $-2.67^{\star}$ & 1.5500 & -0.45 & -9.94 ** & -6.56 ** & 0.59 \\
\hline \multirow[t]{2}{*}{ log(Tenor) } & -0.13 & 0.71 & -0.23 & -0.36 & -0.52 & 0.27 \\
\hline & $-2.38^{*}$ & $2.57^{*}$ & -1.05 & -3.47 ** & -3.45 & 1.44 \\
\hline \multirow[t]{2}{*}{ Rating Index } & -0.04 & 0.20 & -0.18 & -0.28 & 0.05 & -0.05 \\
\hline & $-2.82^{\star \star}$ & $3.55^{\star \star}$ & $-3.38^{\star \star}$ & $-7.77^{\star \star}$ & 0.48 & -0.81 \\
\hline \multirow[t]{2}{*}{ Fixed } & 1.02 & -0.57 & 1.04 & 0.46 & 0.46 & all fixed \\
\hline & $14.23^{* *}$ & -1.84 & 3.59 ** & $3.77^{\star \star}$ & $2.87^{\text {** }}$ & \\
\hline \multirow[t]{2}{*}{ CA/GDP } & -0.064 & -0.095 & -0.260 & -0.161 & -0.089 & -0.027 \\
\hline & $-2.25^{\star}$ & -0.70 & $-2.46^{*}$ & $-3.80 * *$ & -1.43 & -0.31 \\
\hline \multirow[t]{2}{*}{ CIP } & 58.7 & $1 /$ & 186.0 & $\begin{array}{l}37.4 \\
67 * \star\end{array}$ & 29.2 & $1 /$ \\
\hline & & & & & & \\
\hline \multirow[t]{2}{*}{$\mathrm{i}^{\mathrm{I}}-\mathrm{i}^{\mathrm{H}}$} & -1.31 & $2 /$ & -5.09 & -0.80 & -0.74 & $2 /$ \\
\hline & $-6.42^{* *}$ & & 0.00 ** & $-5.42^{* *}$ & $-4.94^{* *}$ & \\
\hline \multirow[t]{2}{*}{ year } & 0.05 & -0.01 & 0.03 & -0.05 & 0.00 & 0.09 \\
\hline & $4.67^{\star \star}$ & -0.1 & $0.73^{* \star}$ & $-2.6 * \star$ & -0.07 & 2.25 * \\
\hline No obs. & 4,498 & 432 & 242 & 1,817 & 1,214 & 1,474 \\
\hline Pseudo Rsq & 0.74 & 0.21 & 0.54 & 0.72 & 0.73 & 0.04 \\
\hline
\end{tabular}

Dependent variable is 1 if the bond is issued offshore and 0 is issued onshore.

Note: ** indicates significance to the $1 \%$ level; * indicates significance to the $5 \%$ level

$1 /$ CIP not equal to zero predicts offshore issuance perfectly. Corporates typically lower rated than AA banks, so FC issuance looks like a bargain.

2/ Dropped because of collinearity

$3 /$ Excludes sub-investment grade ABS issuance which is not issued publicly, but retained on bank balance sheets ("skin in the game"). 


\section{References}

Alfaro, L, S. Kalemli-Ozcan and V Volosovych (2005), "Why doesn't Capital Flow from Rich to Poor Countries? An Empirical Investigation", NBER Working Paper No W11901, National Bureau of Economic Research.

Allayannis, G. and E. Ofek (2001), "Exchange rate exposure, hedging and the use of foreign currency derivatives", Journal of International Money and Finance, Vol. 20, 273-296.

Australian Securities and Investment Commission (ASIC) (2008), "Australia and Hong Kong sign deal to allow cross-border marketing of retail funds", Media release 08-152, (www.asic.gov.au).

Bae, K.H., R. Stulz and H Tan (2008), "Do local analysts know more? A cross-country study of performance of local analysts and foreign analysts", Journal of Financial Economics, 2008, v88(3), 581-606.

Baker, M., R. Greenwood and J. Wurgler (2003), "The maturity of debt issues and predictable variation in bond returns", Journal of Financial Economics, 70, 261-291.

Bank for International Settlements (2006), Asian bond markets: issues and prospects, BIS Papers No 30, November 2006.

Battellino, R. and M. Chambers (2005), "An overview of the Australian corporate bond market", BIS Papers No. 26, 45-55.

Becker, C., Debelle, G., Fabbro, D. (2005), "Australia's foreign currency exposure and hedging practices", Bulletin, Reserve Bank of Australia, December, 1-8.

Borensztein, E. and U. Panizza (2006), "Building bond markets in Latin America", Prepared for an IADB network on the growth of corporate bond markets in Latin America.

Burger, J. and F. Warnock (2004), "Foreign participation on local-currency bond markets", Board of Governors of the Federal Reserve System International Finance Discussion Papers, February.

Cameron, L., B. Chapple, N. Davis, A. Kousis and G. Lewis (2007), "New Zealand Financial Markets, Saving and Investment", New Zealand Treasury Policy Perspectives Paper 07/01, October.

Committee for the Global Financial System (1999), Liquidity, Committee for Global Financial Stability, Bank for International Settlements.

Cohen, B. (2005), "Currency choice in international bond issuance", BIS Quarterly Review, June 2005.

Cuthbertson J. (1957), "The Term Structure of Interest Rates", Quarterly Journal of Economics, 71, 485-517.

Drage, D., A. Munro and C. Sleeman (2005), "An update on Eurokiwi and Uridashi bonds", Reserve Bank of New Zealand Bulletin, Vol. 68, no. 3, 28-38.

Eichengreen B. and Hausmann (1999), "Exchange Rates and Financial Fragility", in Federal Reserve Bank of Kansas City, New Challenges for Monetary Policy.

Faulkender, M. (2005), "Hedging or market timing? Selecting the interest rate exposure of corporate debt", The Journal of Finance, Vol IX No. 2, April, 931-962.

Fletcher, D. and L. Taylor (1996), "Swap covered interest parity in long-date markets", The Review of Economics and Statistics, Vol 78, No 3 (August), 530-538, The MIT Press.

Geczy, C., B Minton and C. Strand (1997), Geczy, C., "Why firms use derivatives: Distinguishing among existing theories", The Journal of Finance, Vol. 52, No.4 (September 19997), 1324-1354. 
Graham, J. and C. Harvey (2001), "The theory and practice of corporate finance: evidence from the field", Journal of Financial Economics, Vol. 60, Issues 2-3, May 2001, 187-243.

Hale, G and J Santos (2008), "The decision to first enter the public bond market: The role of firm reputation, funding choices and bank relationships", Journal of Banking and Finance, Vol 32, Issue 9, September 2008, 1928-1940.

Henry, P. B. (2006), "Capital Account Liberalization: Theory, Evidence and Speculation", Journal of Economic Literature, Vol. 46, Issue 4, pp 989-1041.

Herrera Pol (2004), "The opening of new markets to foreign issuers: What has changed in the new millennium?", in The Euromoney International Debt Capital Markets Handbook 2005, Euromoney Institutional Investor.

Kedia, S. and A. Mozumdar (2003), "Foreign currency-denominated debt: an empirical examination", The Journal of Business, vol. 76, no. 4.

Kose, M. A., E. Prasad, K. Rogoff, S. J. Wei (2006), "Financial Globalisation: A Reappraisal", NBER Working Papers No 12484, National Bureau of Economic Research.

McBrady and Schill (2007), "Foreign currency-denominated borrowing in the absence of operating incentives", Journal of Financial Economics, Vo 86, Issue 1, October 2007, 145-177.

Miller, D. and J. Puthenpurackal (2005), "Security, fungibility and the cost of capital: evidence from global bonds", ECB Working Paper No. 42, January.

Modigliani F. and R. Sutch (1966), "Innovations in Interest Rate Policy", American Economic Review, May.

Munro, A. and P Wooldridge (2009), "Motivations for swap-covered foreign currency borrowing", preliminary draft.

Park, D. and C. Rhee (2006), "Building infrastructure for Asian bond markets: settlement and credit rating", BIS Papers No. 30.

Peel, D. A. and M. P. Taylor (2002), "Covered interest rate arbitrage in the interwar period and the Keynes-Einzig Conjecture, Journal of Money, Credit and Banking 34, 51-75.

Peristiani, S and J. Santos (2008), "Has the US Bond market Lost its Edge to the Eurobond Market?", unpublished paper, Federal Reserve bank of New York, February 2008.

Popper, H. (1993), "Long term covered interest parity: evidence from currency swaps", Journal of International Money and Finance, 12, 439-448.

Reserve Bank of Australia (2006), "Australian banks' global bond funding", Reserve Bank of Australia Bulletin, August 2006.

Ryan, C. (2007), "Some general observations on the Kangaroo bond market", Reserve Bank of Australia Bulletin, April, 10-17.

Siegfried, N., E. Simeonova and C. Vespro (2007), "Choice of currency in bond issuance and the international role of currencies", ECB Working Paper series No. 814, September.

Statistics New Zealand (2008), "Balance of Payments and International Investment Position: Year ended 31 March 2008)", available on the Statistics New Zealand Website.

Stulz, R (1981), "On the effects of Barriers to International Investment", The Journal of Finance, Vol 36, No 4 (Sept) pp 923-934.

Stulz, R. (2005), "The Limits of Financial Globalization", ECGI - Finance Working Paper No. 75/2005 , Dice Center Working Paper No. 2005-1.

Takeuchi, A. (2006), "Identifying the impediments to cross-border investment and issuance in Asian countries", BIS Papers No 30, pp 246-280. 
Taylor, M.P. (1987), "Covered interest parity: a high-frequency, high-quality data study", Economica 54, 429-38.

Tyler, S. (2005), “The New Zealand corporate bond market”, BIS Papers No. 26, 129-35.

Vayanos D. and J LVila (2007), "A Preferred Habitat model of the Term Structure of Interest Rates", http://personal.Ise.ac.uk/vayanos/WPapers/PHMTSIR.pdf 